\title{
EFFECTIVENESS OF THE COMPOUND HELICOPTER CONFIGURATION IN ROTORCRAFT PERFORMANCE INCREASE
}

\author{
Jarosław Stanisławski \\ Retired doctor of technical sciences \\ jar55stan19@gmail.com• ORCID: 0000-0003-1629-4632
}

\begin{abstract}
The article presents the results of calculations applied to compare flight envelopes of varying helicopter configurations. Performance of conventional helicopter with the main and tail rotors, in the case of compound helicopter, can be improved by applying wings and pusher propellers which generate an additional lift and horizontal thrust. The simplified model of a helicopter structure, consisting of a stiff fuselage and the main rotor treated as a stiff disk, is applied for evaluation of the rotorcraft performance and the required range of control system deflections. The more detailed model of deformable main rotor blades, applying the Galerkin method, is used to calculate rotor loads and blade deformations in defined flight states. The calculations of simulated flight states are performed considering data of a hypothetical medium class helicopter with the take-off mass of $6,000 \mathrm{~kg}$. In the case of both of the helicopter configurations, the articulated main rotor hub is taken under consideration. According to the Galerkin method, the elastic blade model allows to compute blade deformations as a combination of the blade bending and torsional eigen modes. Introduction of additional wing and pusher propellers allows to increase the range of operational speed over $300 \mathrm{~km} / \mathrm{h}$. Results of the simulation are presented as timeruns of rotor loads and blade deformations and in a form of disk distribution plots of rotor parameters. The simulation method can be useful in defining requirements for a high speed rotorcraft.
\end{abstract}

Keywords: compound helicopter, rotor loads, blade deformations

\section{INTRODUCTION}

The main feature of a helicopter is its capability of hovering and flying at low speed conditions. Nonetheless, a helicopter's operational envelope is limited due to the high speed flights. Mutual influence of the helicopter's speed and velocity of rotating blades generate effects of high Mach number for advancing blade and a zone of high attack angles for retreating blade. Deficiencies of the conventional helicopter configuration can be corrected by applying the compound configuration which consists of additional lifting wings and propellers generating propulsive thrust. In the case of a compound helicopter, usage of the additional wings and propellers allow to decrease loads of the main rotor blades at the range of flights with high speed.

Among the early attempts of application of the lifting wings and propulsive propellers aiming to improve the rotorcraft performance stands out the Fairey Rotodyne developed in the 1950s [1]. That large 
passenger rotorcraft was able to take-off and land vertically in the helicopter mode and could fly at the cruise speed of $300 \mathrm{~km} / \mathrm{h}$ in autogiro mode with a reduced lifting thrust of the main rotor. Experimental compound helicopters in the 1960s and in the 1970s such as: Lockheed XH-51A, Bell-533, Sikorsky XH-59, Sikorsky S-72 RSRA (Rotor System Research Aircraft) [2] were developed to research the effects of application of the wings and additional turbojet engines to reach flight speed of over 400 $\mathrm{km} / \mathrm{h}$. Tested in the late 60s, the attack helicopter AH-56A Cheyenne, besides the main and tail rotor was equipped with a variable-pitch pusher propeller which allowed the aircraft to accelerate or decelerate very quickly without pitching the fuselage nose up or down. The main rotor was partially offloaded during cruising flight by set of wings. Unfortunately, the crash during rotorcraft tests and subsequent financial problems stopped the development of the program [3]. Amongst the other winged versions of compound helicopters can be mentioned: serial Mil Mi-6 [4], a test version of Chinook, model BV347 equipped with tandem rotors [5] anda French single-rotor SA 349.2 Gazelle [6]. The next wave of increased tests of compound helicopters could be observed in the 2000 s decade. The then new experimental compound helicopters [7] included: the American Piasecki X-49 Speedhawk, the Sikorsky X2 and the French Eurocopter X3, the latter of which set an unofficial speed record for propeller helicopters achieving speed of $472 \mathrm{~km} / \mathrm{h}$ in level flight. It is worth to mention that the pioneering tests of compound helicopters were also conducted in Poland - in 1971 at the Institute of Aviation was tested the winged variant of the SM-1 helicopter (license built Mil Mi-1) [8]. Also a compound version of the IS-2 light helicopter equipped with wings and propeller-ventilators, was analyzed in Poland during the designing phase [9].

Arising interest in compound rotorcrafts can be noticed considering the newest U.S. Army programs: FARA (Future Attack Reconnaissance Aircraft) and FLRAA (Future Long-Range Assault Aircraft). At the current phase of the FARA program the Army has selected two projects [10]. One of them is the Raider X designed by Sikorsky in a coaxial configuration with a tail pusher propeller as a scaled-up version of the S-97 Raider and the other project is the Bell 360 Invictus - a winged helicopter with a single rotor and ducted tail rotor. For the FLRAA program [11] Army selected the tilt-rotor Bell V-280 Valor and the Sikorsky/Boeing $\mathrm{SB}>1$ Defiant coaxial helicopter with a tail pusher propeller. During tests in 2019 , the V-280 reached top flight speed of 300 knots $(556 \mathrm{~km} / \mathrm{h})$.

The new Russian compound helicopters include, among others, Mi-24LL PSV (Perspektivny Skorostnoj Vertolet (stands for high-speed helicopter) [12] which is a modified Mi-24 helicopter with a sleek-winged fuselage and renewed main rotor blades with modified shape of the tips. Other unveiled projects are Mil Mi-X1, designed in the single main rotor configuration with a vectored thrust tail propeller [13] and project of the Kamov Ka-92 which will feature a coaxial rotor system and tail pusher propeller. The Ka-92 is designed as a heavy helicopter with the take-off mass of 16 tons and capability of cruising at the speed of about $500 \mathrm{~km} / \mathrm{h}$. In Europe the Airbus RACER (Rapid And Cost-Effective Rotorcraft) is being developed within EU's Clean Sky program [15]. The RACER is a compound helicopter featuring twin pusher propellers mounted on V-shaped box-wings. It is optimized for a cruise at the speed of $400 \mathrm{~km} / \mathrm{h}$ and its maiden flight is planned for the year 2021 .

Experimental research and analytical works were focused on examining following features of compound helicopters: rotor-wing lift sharing [16], level flight and maneuver characteristics [17], handling qualities [18], effects of varying the main rotor blade tip speed [19], [20], [21] and investigation of the dynamic stability characteristics [22]. Some innovative applications of compound helicopters were considered. NASA investigated a heavy-lift system of large rotorcraft intended for use in the civil transport [23], [24] which included a tiltrotor, tandem rotors compound with auxiliary propulsion provided with two wing-mounted propellers and the Advancing Blade Concept compound with coaxial rotors and a tailmounted pusher propeller. A smaller helicopter with the takeoff mass of about $4,000 \mathrm{~kg}$ was studied as the Coaxial Compound Helicopter (CCH) [25] for military operations in a confined urban environment. Analysis showed that in urban canyons of high buildings and infrastructure rotorcraft operational 
requirements were well satisfied by the coaxial rotor configuration with lift compounding and ducted fans for propulsion. For a compound helicopter with mixed and multiplied sources of lift and thrust propulsion the multi-objective optimization of aerodynamic interactions and structural dynamics is required [26], [27]. By the application of aerodynamic simulation the aeroacoustic characteristics of the RACER helicopter were predicted. The study was focused on noise emission due to interactions among wings, the rotor and propellers in various flight conditions [28]. A non-symmetric lift compound concept was checked in the wind tunnel [29]. In that compound case an additional single wing was fixed on the retreating blade side which mutually allowed to compensate rolling moment generated at the rotor hub at high-speed flight on the advancing blade side

Presented in this paper results of calculations were collected for data of a hypothetical helicopter of medium class with the takeoff mass of $6,000 \mathrm{~kg}$. The aim was to check possibilities of enlarging the operational flight speed envelope for a helicopter with articulated connection of the blades and rotor hub by applying wings for lift compounding and additional propellers for thrust compounding. Assumed configuration of the considered compound helicopter includes a winged fuselage, single main rotor, tail rotor and additional tail-mounted pusher propellers (Fig. 1). In the range of high-speed flight the wings allow to offload the main rotor and additional propellers with horizontally vectored thrust help to overcome rising aerodynamic drag of the helicopter.

a)
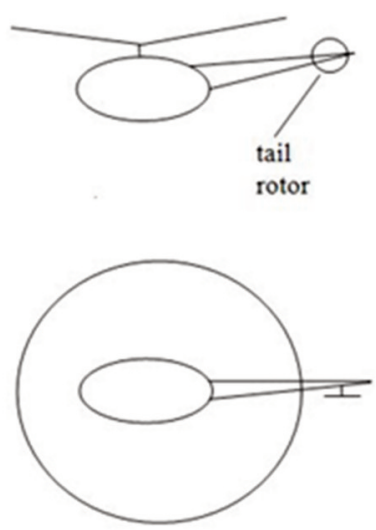

b)
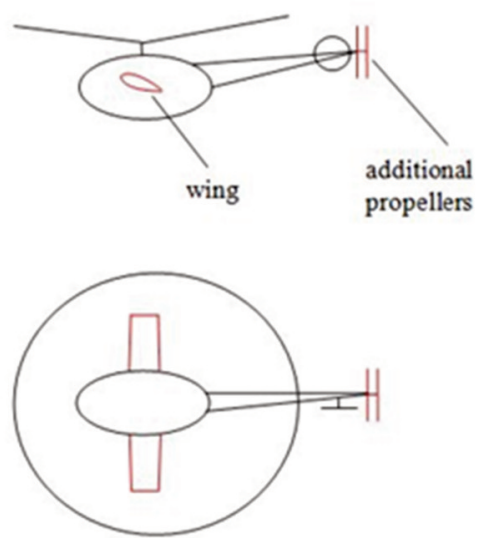

Fig. 1. Configurations of helicopter versions: a) conventional, b) compound with wings and additional propellers.

Simulation calculations of the rotorcraft performance were executed both for conventional and compound configurations of helicopters. By applying the non-deformable model of a rotor disk the data concerning performance of helicopter were compared for a four-, five- and six-bladed rotor variants with different cases of the rotor blade tip speed: higher, equal to $220 \mathrm{~m} / \mathrm{s}$ and lowered to $190 \mathrm{~m} / \mathrm{s}$. The deformable blade model was applied for analysis of the rotor thrust and blade deflections for limited cases of flight speed at 250,325 and $400 \mathrm{~km} / \mathrm{h}$ for rotor with the blade tip speed equal to $190 \mathrm{~m} / \mathrm{s}$. Calculations of rotor thrust and blade deflections, changing during a rotor revolution, were performed for two versions of blades with different stiffness. In the case of the softer blades applied for conventional helicopter and in the case of the stiffened blades assumed for compound configuration which allows to diminish oscillations of the rotor at high-speed flight. Application of the simulation method can be useful in defining correct parameters of rotor blades which may help to avoid harmful vibration of the helicopter structure at the high-speed flight range. 


\section{MODEL OF HELICOPTER}

The simplified model of a helicopter structure was used to calculate the rotorcraft performance, equilibrium conditions and desired deflections of control units due to changes of flight speed. The applied model consists of a stiff fuselage with assigned aerodynamic characteristics and the main rotor treated as a stiff disk. At a given flight speed in the iterative process, the balance conditions of a helicopter are computed. For the determined state of helicopter equilibrium, desired deflections of the swashplate and pitch of the tail rotor blades can be defined. In Fig. 2 is shown the scheme of geometric data and forces applied to define longitudinal balance of helicopter.

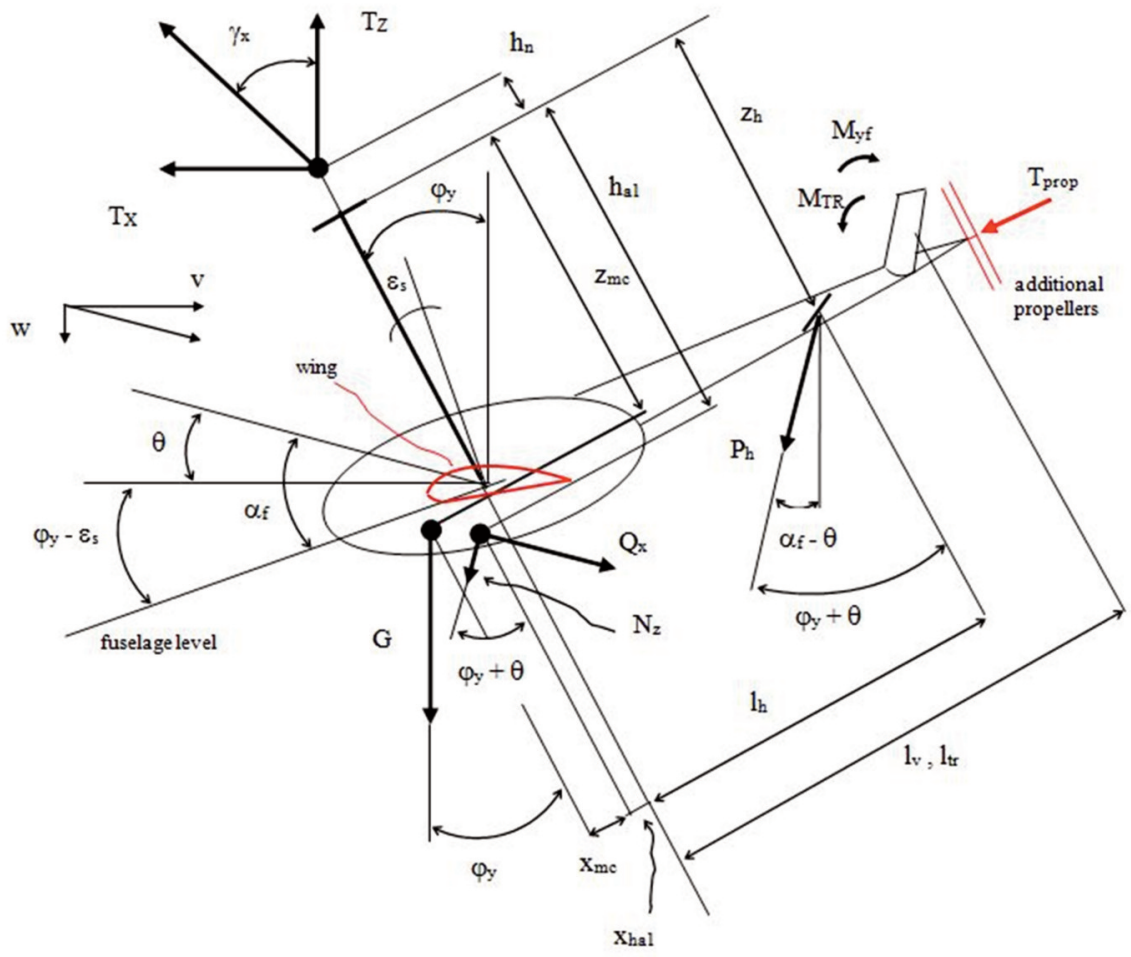

Fig. 2. Scheme of helicopter geometry and loads in longitudinal plane.

The following parameters are shown in Fig. 2:

$\mathrm{w}, \mathrm{v}-$ components of flight speed,

$\theta \quad-$ flight path angle, where $\theta=\operatorname{arctg}(\mathrm{w} / \mathrm{v})$,

$\varphi_{\mathrm{y}} \quad-$ pitch angle of rotor shaft,

$\varepsilon_{\mathrm{s}} \quad-$ built-in angle of rotor shaft axis due to fuselage vertical position,

$\alpha_{f} \quad-$ fuselage angle of attack,

$\mathrm{T}_{\mathrm{X}}, \mathrm{T}_{\mathrm{Z}}$ - components of the main rotor thrust,

$\mathrm{T}_{\text {prop }}$ - thrust of additional tail-mounted propellers,

G - helicopter weight,

$\mathrm{Q}_{\mathrm{x}} \quad$ - fuselage drag,

$\mathrm{N}_{\mathrm{z}} \quad-$ lift of fuselage, 
$\mathrm{P}_{\mathrm{h}} \quad-$ lift of horizontal stabilizer,

$\mathrm{M}_{\mathrm{yf}} \quad$ - aerodynamic moment of fuselage (includes effect of added wing),

$\mathrm{M}_{\mathrm{TR}} \quad-$ moment of tail rotor,

$\mathrm{x}_{\mathrm{mc}}, \mathrm{z}_{\mathrm{mc}}$ - location of helicopter mass center due to rotor hub center,

$h_{n} \quad-$ height over rotor hub of suspension point for helicopter treated as a physical pendulum,

$\mathrm{h}_{\mathrm{a} 1}, \mathrm{x}_{\mathrm{hal}}$ - location of fuselage aerodynamic forces due to rotor hub center,

$1_{h}, 1_{v}, l_{t r}$ - distances of horizontal stabilizer, fin, axis of tail rotor due to main rotor axis,

$\mathrm{z}_{\mathrm{h}} \quad-$ height of main rotor hub over horizontal stabilizer.

The fuselage lift force $N_{z}$ and drag force $Q_{x}$ depend on components of flight speed and fuselage angle of attack $\alpha_{f}$ :

$$
\begin{aligned}
& Q_{x}=\frac{1}{2} \rho \cdot\left(v^{2}+w^{2}\right) \cdot \pi R^{2} \cdot c_{x f}\left(\alpha_{f}\right), \\
& N_{z}=\frac{1}{2} \rho \cdot\left(v^{2}+w^{2}\right) \cdot \pi R^{2} \cdot c_{z f}\left(\alpha_{f}\right),
\end{aligned}
$$

where

$\rho$ - density of air ,

$c_{x f}\left(\alpha_{f}\right), c_{z f}\left(\alpha_{f}\right)$ - fuselage drag and lift coefficients (include effects of added wing),

$R$ - main rotor radius.

Applying force equilibrium conditions the components of main rotor thrust are as follows:

$$
\begin{aligned}
& T_{X}=Q_{x} \cos \left(\alpha_{f}-\theta\right)-N_{z} \sin \left(\alpha_{f}-\theta\right)-P_{h} \sin \left(\alpha_{f}-\theta\right)-T_{\text {prop }} \cos \left(\phi_{y}\right), \\
& T_{Z}=Q_{x} \sin \left(\alpha_{f}-\theta\right)+N_{z} \cos \left(\alpha_{f}-\theta\right)+P_{h} \cos \left(\alpha_{f}-\theta\right)+G+T_{\text {prop }} \sin \left(\phi_{y}\right),
\end{aligned}
$$

Treating the helicopter as a physical pendulum the fuselage pitch angle $\varphi_{y}$ can be calculated applying equation of moments acting on helicopter:

$$
\begin{aligned}
& G\left(h_{n}+z_{m c}\right) \sin \phi_{y}-G x_{m c} \cos \phi_{y}-P_{h} l_{h} \cos \left(\phi_{y}+\theta\right)+P_{h}\left(h_{n}+z_{h}\right) \sin \left(\phi_{y}+\theta\right) \\
& +N_{z}\left(h_{n}+h_{a 1}\right) \sin \left(\phi_{y}+\theta\right)-N_{z} x_{h a 1} \cos \left(\phi_{y}+\theta\right)-Q_{x}\left(h_{n}+h_{a 1}\right) \cos \left(\phi_{y}+\theta\right) \\
& -Q_{x} x_{\text {ha } 1} \sin \left(\phi_{y}+\theta\right)+T_{p r o p}\left(h_{n}+z_{\text {prop }}\right)+M_{y f}+M_{T R}=0
\end{aligned}
$$

The height of pendulum suspension point over rotor hub is as follows:

$$
h_{n}=\frac{k \cdot S_{h h} \cdot(\Omega R)^{2} \cdot l_{h h}}{2 \cdot T \cdot R^{2}}
$$

where

$l_{h h}$ - distance of flapping hinge measured from rotor shaft axis,

$S_{h h}$ - static mass moment of blade about flapping hinge,

$k$ - number of rotor blades,

$R$ - radius of rotor blade,

$\Omega$ - rotational speed of main rotor,

$T-$ main rotor thrust. 
For defined force balance of helicopter, the value of rotor blade collective pitch $\vartheta_{o}$ can be determined as a function of dimensionless coefficients $\mu_{o}$, rotor advance ratio and $\lambda_{o}$ rotor inflow ratio:

$\vartheta_{o}=\frac{c_{T}^{*}+\vartheta_{s}\left(t_{4}+0,5 \mu_{o}^{2} t_{2}\right)+\lambda_{o}\left(t_{2}+2 \mu_{o}^{2}\right)}{t_{3}+0,5 \mu_{o}^{2} t_{1}}$,

where

$c_{T}^{*}$ - coefficient of the main rotor thrust,

$\vartheta_{S}-$ geometric twist of rotor blade,

$t_{1}, t_{2}, t_{3}, t_{4}$ - geometric constants depend on tapered shape of blade defined as follows:

$t_{n}=4 \int_{\bar{\gamma}_{1}}^{\bar{r}_{2}} \frac{b}{b_{o}} \bar{r}^{(n-1)} d \bar{r}$,

where

$\bar{r}_{1}, \bar{r}_{2}$ - relative radius, aerodynamic non-active at root and tip of rotor blade,

$b_{o}-$ theoretical chord of rotor blade in the middle of rotor hub,

$b$ - current chord of rotor blade.

Following equation defines the main rotor thrust coefficient $c_{T}^{*}$ :

$c_{T}^{*}=\frac{8 T}{\rho \Omega^{2} R^{3} a k b_{07}}$,

where

$a=d c_{z} / d \alpha-$ airfoil lift curve slope,

$k$ - number of rotor blades,

$b_{07}-$ chord rotor blade at radius $\mathrm{r}=0,7 \mathrm{R}$.

Swashplate deflection angles $\theta_{t x}$ and $\theta_{t y}$ about axis of the rotor shaft are determined by taking into account the blade flapping coefficients $a_{1 y}, b_{1 y}$ and parameters of helicopter balance - the tail rotor thrust $T_{T R}$, main rotor thrust $T$ and angle of helicopter rolling $\varphi_{x}$ and pitching $\varphi_{y}$ :

- swashplate pitching angle

$\theta_{t y}=\frac{\left(a_{1 y}-\phi_{y}+\gamma_{x}\right) D_{1}-\left(\phi_{x}-T_{T R} / T-b_{1 y}\right)}{D_{1}^{2}+D_{2}^{2}}$,

- swashplate rolling angle

$\theta_{t x}=\frac{b_{1 y}-\phi_{x}+T_{T R} / T-D_{2} \theta_{t y}}{D_{1}}$,

where $D_{1}, D_{2}$ - geometric coefficients of the blade pitch control system.

The more exact model of flexible blades is applied for calculations of rotor loads and blade deformations in defined states of flight speed. The elastic blade model according to the Galerkin method allows to compute blade deformations as a combination of bending and torsional eigen modes of a blade. 
Changing during a rotor revolution deflections of the blades, airflow components and effects of the blade pitch control mutually induce generating of forces and moments at the blades and rotor hub. The model of the main rotor blade with elements of a hub arm includes lumped masses set attached to the elastic axis. The physical model of a rotor blade is shown in Fig. 3.

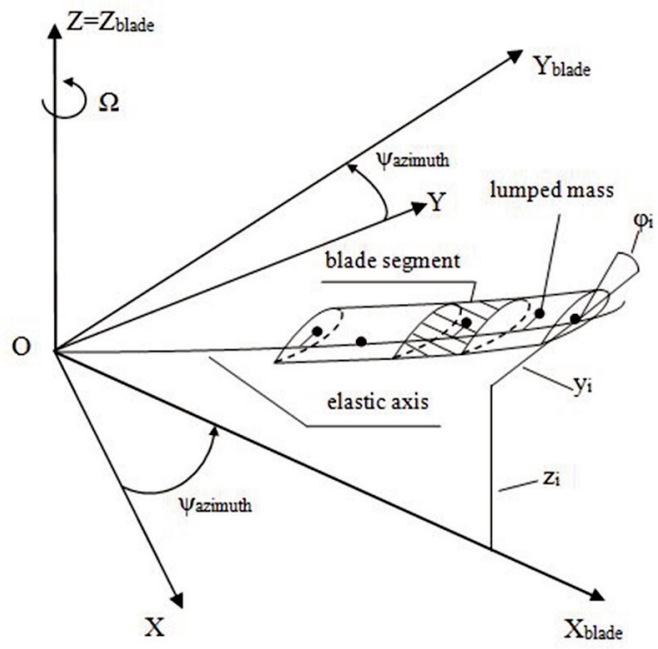

Fig. 3. Model of a rotor blade includes elastic axis with a set of lumped masses.

The calculation model consists of equations of motion for flexible rotor blades which include effects of torsion deflections, as well as the in-plane and out-of-plane bending of the blade elastic axis.

The equations of rotor blades motion are solved using the Runge-Kutta method. According to the Galerkin method, the motion parameters of the blade elastic axis are assumed as a combination of shares of the considered eigen modes of the rotor blades. The deflections of the blade elastic axis $y, z, \varphi$ are treated as equal to superposition of modal components:

$y(x, t)=\sum_{i 1=1}^{I 1} \rho_{i 1}(t) y_{i 1}(x) ; \quad z(x, t)=\sum_{i 2=1}^{I 2} \delta_{i 2}(t) z_{i 2}(x) ; \quad \varphi(x, t)=\sum_{i 3=1}^{I 3} \eta_{i 3}(t) \varphi_{i 3}(x)$,

where

$\mathrm{y}_{\mathrm{i} 1}, \mathrm{z}_{i 2}, \varphi_{i 3}$ - eigen modes of in-plane, out-of-plane bending and torsion respectively,

$\rho_{i 1}, \delta_{i 2}, \eta_{i 3}$ - time-dependent shares of eigen modes, which are determined in computing process,

$I 1, I 2, I 3-$ numbers of considered bending and torsion eigen modes.

Taking into account formulas (12), the equations of blade motion can be transformed into sets of equations (13) related to each of the considered blade eigen mode:

$$
\begin{array}{ll}
\ddot{\rho}_{i 1}+\rho_{i 1} p_{i 1}^{2}=Q_{Y_{i 1}} & \mathrm{i} 1=1, \ldots, \mathrm{I} 1 \\
\ddot{\delta}_{i 2}+\delta_{i 2} f_{i 2}^{2}=Q_{Z_{i 2}} & \mathrm{i} 2=1, \ldots, \mathrm{I} 2 \\
\ddot{\eta}_{i 3}+\eta_{i 3} v_{i 3}^{2}=Q_{\phi_{i 3}} & \mathrm{i} 3=1, \ldots, \mathrm{I} 3
\end{array}
$$


where

$p_{i 1}^{2}, f_{i 2}^{2}, v_{i 3}^{2}$-square of eigen mode frequencies for bending in-plane, out-of-plane and torsion, $Q_{Y_{i 1}}, Q_{Z_{i 2}}, Q_{\varphi_{i 3}}-$ generalized forces for considered eigen modes of the rotor blade.

Aerodynamic forces acting on a segment of the blade at a given azimuth position on the rotor disk are computed by applying the blade element theory. The local angle of attack at the blade cross-section depends on control of the pitch angle and on temporary conditions of airflow:

$\alpha=\varphi_{\text {coll }}+\varphi_{x_{-} \text {cycl }} \cos \Omega t+\varphi_{y_{-} \text {cycl }} \sin \Omega t+\vartheta_{s}+\Delta \varphi-\kappa_{f p} \beta-\operatorname{arctg}\left(\frac{u_{Z}}{u_{X}}\right)$,

where

$\varphi_{\text {coll }}$ - blade collective control angle,

$\varphi_{x_{-} \text {cycl }}, \varphi_{y_{-} \text {cycl }}-$ cyclic control angle due to roll and pitch deflections of the swash-plate,

$\vartheta_{S}-$ geometric twist,

$\Delta \varphi-$ torsional deformation,

$\kappa_{f p}$ - coefficient of coupling flap and blade pitch,

$\beta$-blade flap angle at horizontal hinge of rotor head,

$u_{z}, u_{x}$ - components of the cross-section airflow of rotor blade: out-of-plane and in-plane.

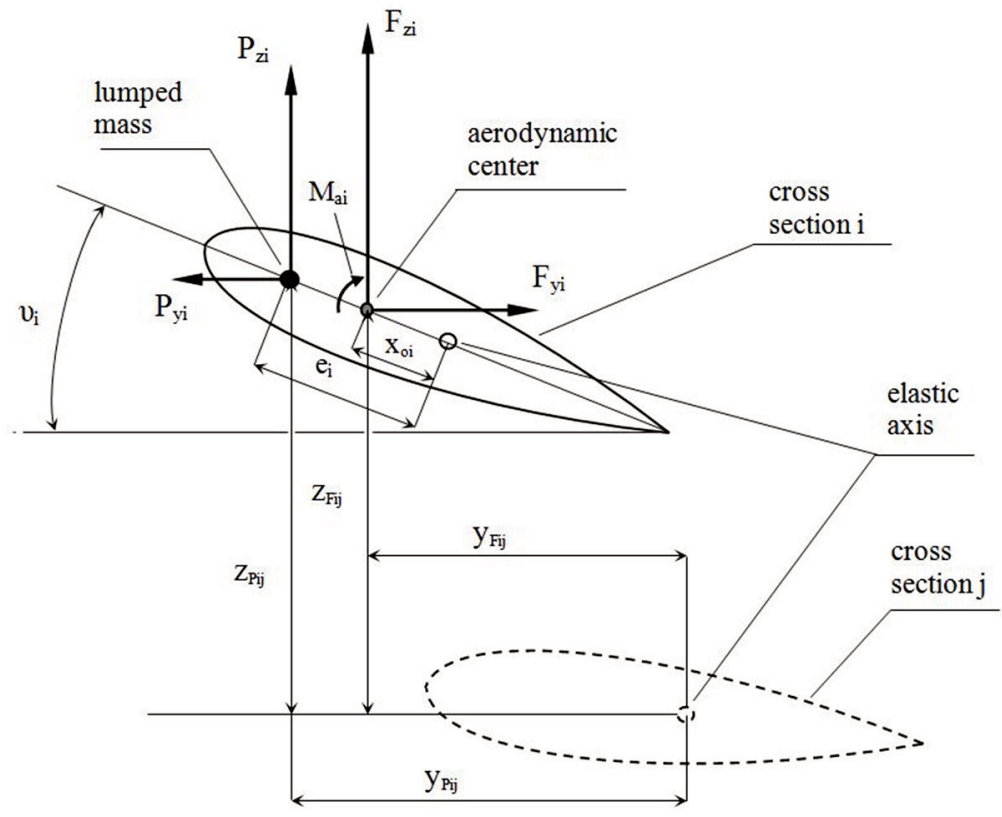

Fig. 4. Scheme of components of the torsional moment in the cross-section of a rotor blade.

The level of loads at the rotor control system largely depends on torsion moments acting on the rotor blades. For elastic blade the torsion moment in $j$ cross-section depends on the relative displacements of blade outer cross-sections and local distribution of aerodynamic and inertial loads at blade segments (Fig. 4). The local torsion moment in $j$ cross-section of elastic axis due to aerodynamic and inertial loads acting in $i$ section is defined as follows: 


$$
M_{x j}=\left(P_{z i}+P_{x i} \cdot \Delta \alpha_{i j}\right) \cdot y_{P i j}-\left(P_{y i}+P_{x i} \cdot \Delta \gamma_{i j}\right) \cdot z_{P i j}+F_{z i} \cdot y_{F i j}+F_{y i} \cdot z_{F i j}+M_{a i}+M_{I i}
$$

where

$P_{z i}, P_{y i}$ - inertial forces of $i$ blade segment out-of rotation plane and in-plane respectively,

$P_{x i} \cdot \alpha_{i j}, P_{x i} \cdot \Delta \gamma_{i j}$ - components of centrifugal force due to differences of bending deflection angles between $i$ and $j$ cross-sections of elastic axis out-of-plane and in-plane

$F_{z i}, F_{y i}$ - aerodynamic forces of $i$ blade segment - lift and drag,

$y_{P i j}, z_{P i j}$ - relative displacement of $i$ and $j$ lumped mass measured in-plane and out-of-plane,

$y_{F i j}, z_{F i j}$ - relative displacement of aerodynamic center at $i$ and $j$ section for in-plane and out-of-plane respectively,

$M_{a i}$ - aerodynamic moment of $i$ blade segment,

$M_{I i}$ - torsional moment of inertial forces of $i$ blade segment:

The simulation algorithm allows for multi-blade analysis in which motion and loads of each blade are calculated for their individual azimuthal position on the rotor disk. For applied time step, forces coming from all of the blades create temporary resultant loads of the main rotor hub. Repeating of computation cycles yields the time-runs of rotor loads and blade deflections.

\section{RESULTS OF CALCULATION SIMULATIONS}

The calculation results of power required for flight, rotor thrust and blade deflections for conventional and compound helicopter configurations are collected in following figures:

- comparison of required power and equilibrium conditions for conventional helicopter with variants of four-, five- and six-bladed rotor and with blade tip speed equal to $190 \mathrm{~m} / \mathrm{s}$ or $220 \mathrm{~m} / \mathrm{s}$ (Fig. 5-10),

- comparison of power required and conditions of equilibrium due to flight speed for compound helicopter with 4-, 5-, 6-bladed rotor for blade tip speed of $190 \mathrm{~m} / \mathrm{s}$ and $220 \mathrm{~m} / \mathrm{s}$ (Fig. 11-17),

- for blade tip speed of $190 \mathrm{~m} / \mathrm{s}$ comparison of blade deflections, blade control moment, thrust of single blade and rotor thrust for conventional and compound helicopters with a 4-, 5-, 6-bladed rotor in the case of soft blades in the level flight condition at speed of $250 \mathrm{~km} / \mathrm{h}$ (Fig. 18-21),

- comparison of time-run for single blade thrust, rotor thrust, blade deflections and blade control moments during rotor revolution for compound helicopter at flight speed equal to 250, 325, 400 $\mathrm{km} / \mathrm{h}$ for a six-bladed rotor in the case of soft and stiff rotor blades (Fig. 22-26),

- rotor disk distributions of blade deflections and attack angle at flight speed of $250,325,400 \mathrm{~km} / \mathrm{h}$ for compound helicopter with a 6-bladed rotor and the blade tip speed equal to $190 \mathrm{~m} / \mathrm{s}$ (Fig. 27-29).

In Fig. 5-17 are shown results received for the non-deformable model of rotor and results presented in Fig. 18-29 are for a model with elastic rotor blades. The simulations in the case of conventional configuration of helicopter were limited to flight speed of $300 \mathrm{~km} / \mathrm{h}$, while in the case of compound helicopter were expanded to flight speed of $400 \mathrm{~km} / \mathrm{h}$. All of the versions of helicopters feature the main rotor with radius of $7.5 \mathrm{~m}$. For the compound configuration area ratio of wings to the main rotor equals $4.67 \%$. The airfoils of the ILH family [30] designed in the Institute of Aviation are assumed to be applied at cross-sections of the main rotor blades. 
In the case of conventional helicopter configuration the lowest values of power required for flight at the range of flight speed higher than $225 \mathrm{~km} / \mathrm{h}$ (Fig. 5a) can be observed for a 6-bladed rotor with the blade tip speed of $190 \mathrm{~m} / \mathrm{s}$. For that rotor case at high speed flight of $300 \mathrm{~km} / \mathrm{h}$ the power required to drive the main rotor is equal to power of the main rotor in hover condition (Fig. 6a). In equilibrium condition the lower power required to drive the main rotor demands lesser value of tail rotor thrust (Fig. 7a).
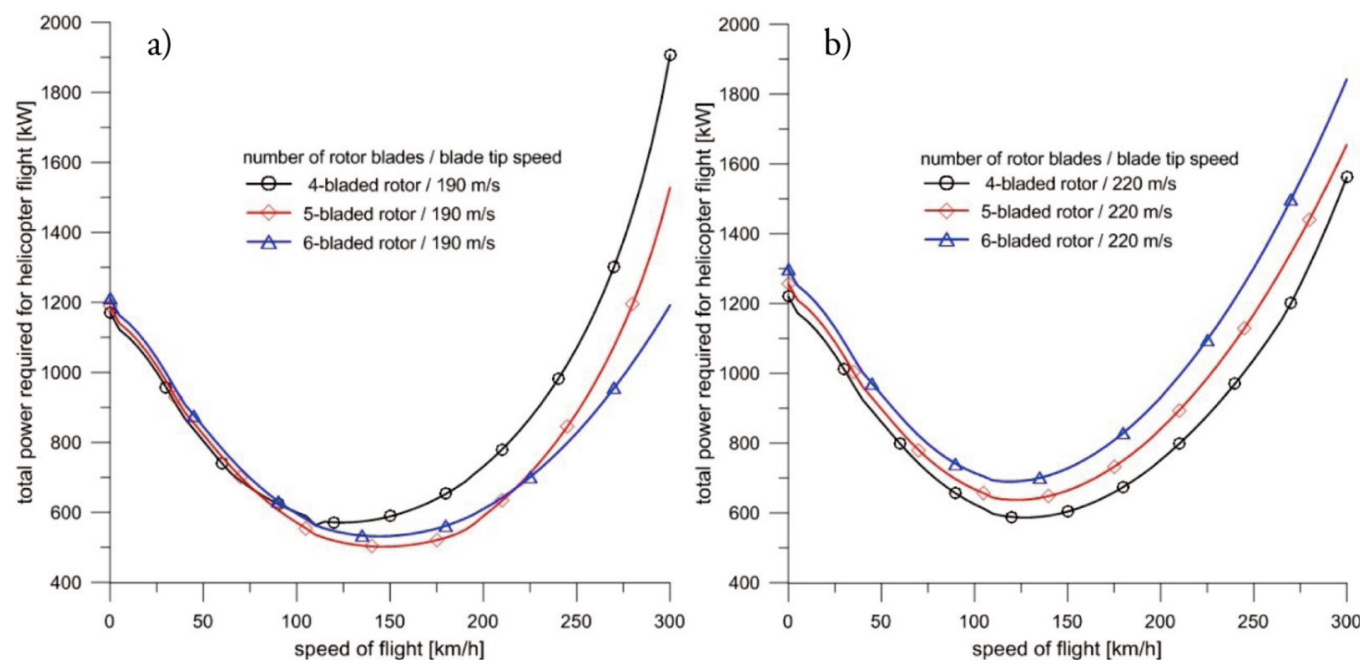

Fig. 5. Total power required for flight for conventional helicopter with the take-off mass of $6,000 \mathrm{~kg}$ the versions for a 4-, 5- and 6-bladed main rotor:

a) the cases with blade tip speed of $190 \mathrm{~m} / \mathrm{s}$,

b) the cases with blade tip speed of $220 \mathrm{~m} / \mathrm{s}$.
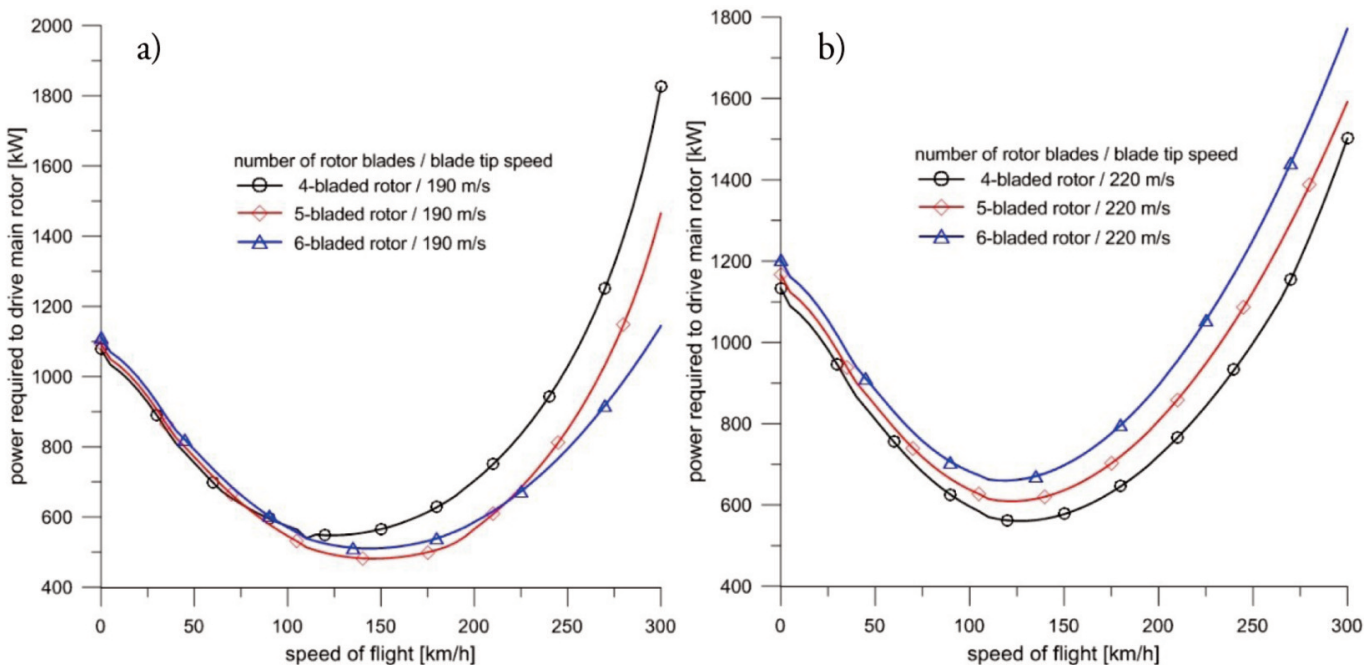

Fig. 6. Power required to drive the main rotor for conventional helicopter with the take-off mass of $6,000 \mathrm{~kg}$, the versions for a 4-, 5- and 6-bladed main rotor:

a) the cases with blade tip speed of $190 \mathrm{~m} / \mathrm{s}$,

b) the cases with blade tip speed of $220 \mathrm{~m} / \mathrm{s}$. 

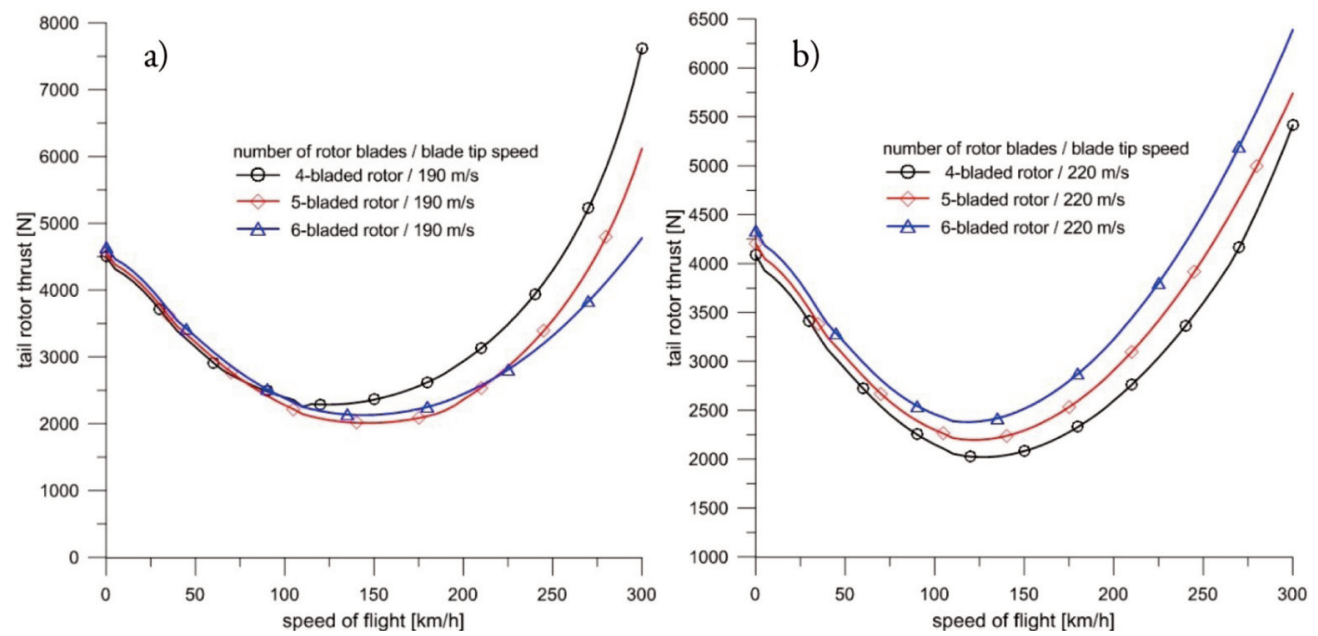

Fig. 7. Changes of tail rotor thrust due to flight speed for conventional helicopter with the take-off mass of $6,000 \mathrm{~kg}$, the versions for a 4-, 5- and 6-bladed main rotor:

a) the cases with blade tip speed of $190 \mathrm{~m} / \mathrm{s}$,

b) the cases with blade tip speed of $220 \mathrm{~m} / \mathrm{s}$.
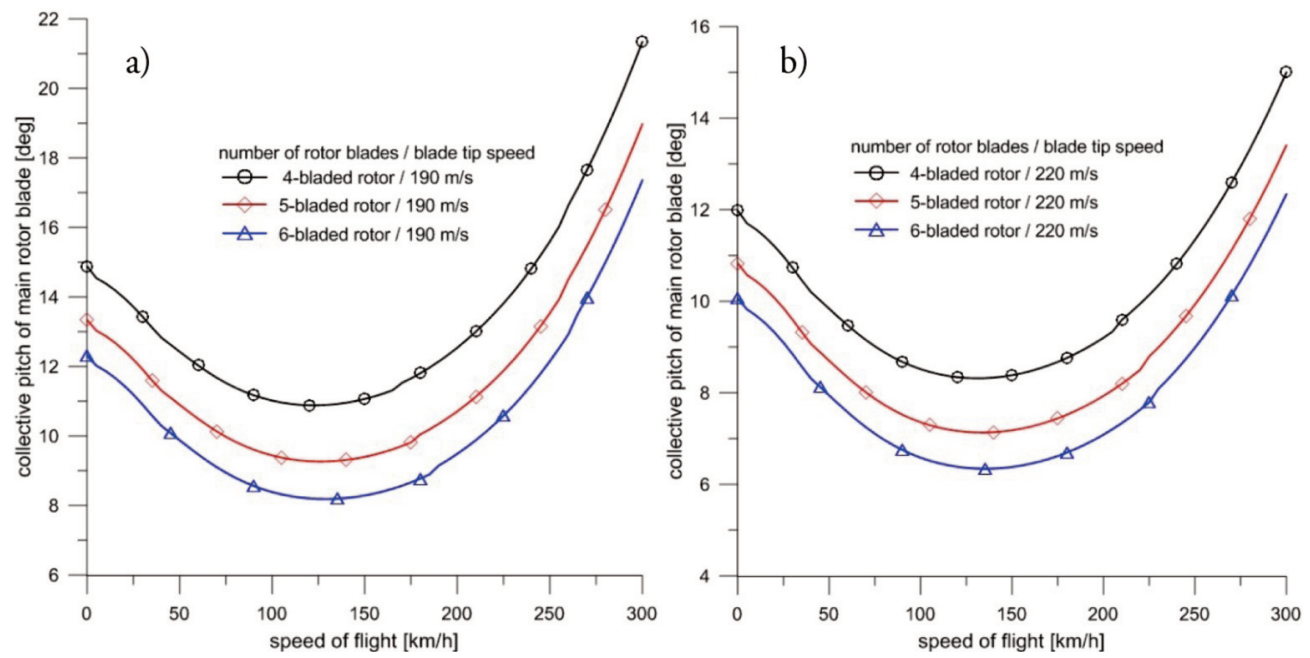

Fig. 8. Changes of collective pitch of the main rotor blades for conventional helicopter with take-off mass of $6,000 \mathrm{~kg}$ in level flight conditions. Versions for 4-, 5- and 6-bladed main rotor:

a) the cases with blade tip speed of $190 \mathrm{~m} / \mathrm{s}$,

b) the cases with blade tip speed of $220 \mathrm{~m} / \mathrm{s}$.

At a given flight speed for a 6-bladed rotor, the lower value of the collective pitch of the main rotor blades (Fig. 8) and lower swashplate deflection (Fig. 9) are necessary to obtain the equilibrium condition. Comparison of the fuselage pitch angle in equilibrium in the cases of conventional and compound helicopter is shown in Fig.10. The sharp change of the plot slope of the equilibrium fuselage pitch angle is connected with change of the airflow character at horizontal stabilizer, for which the separated airflow is observed at flight speed below $100 \mathrm{~km} / \mathrm{h}$. In the case of conventional helicopter the only source of propulsive force is a horizontal component of the rotor thrust which can be enlarged due to the fuselage 
pitch and swashplate deflection. In Fig. 10-17 are shown plots up to speed of $400 \mathrm{~km} / \mathrm{h}$ which concern the results of calculation for the compound helicopter. In the case of the compound helicopter with an additional wing and tail-mounted pusher propellers, the flight at high-speed condition is possible with a small change of the fuselage pitch angle (Fig. 10b) in the position close to the lowest value of fuselage aerodynamic drag coefficient.
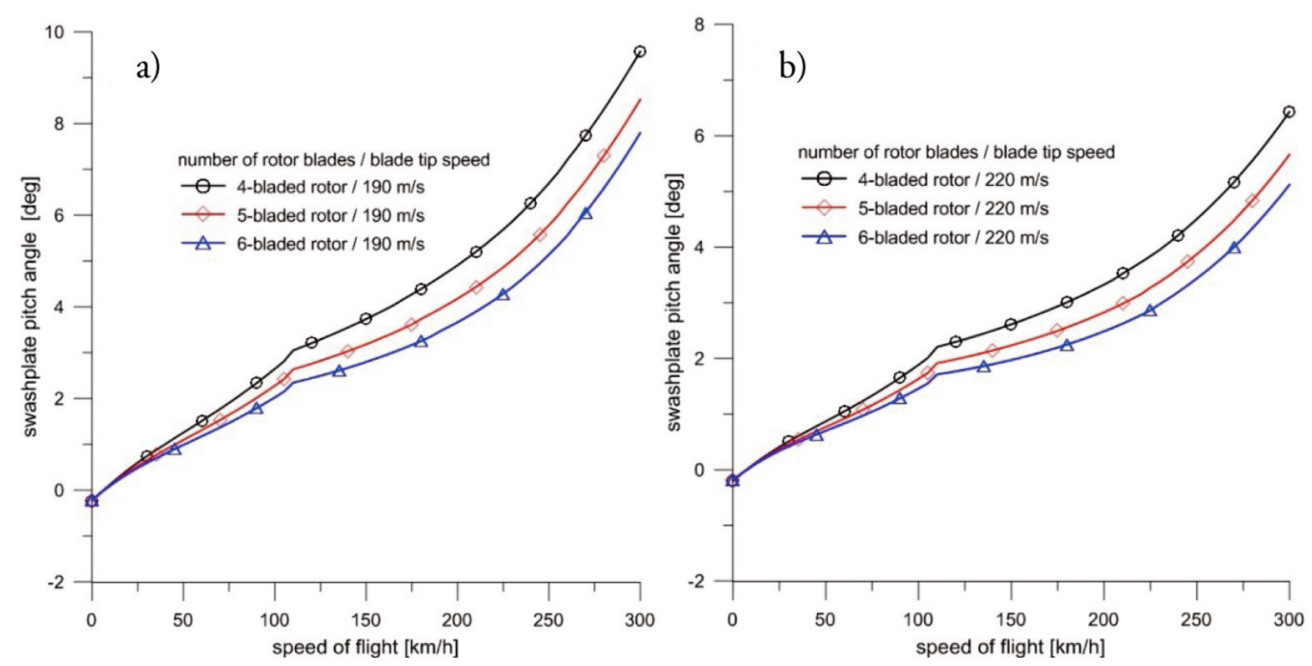

Fig. 9. Changes of the swashplate pitch angle for conventional helicopter with the take-off mass of $6,000 \mathrm{~kg}$ in the level flight conditions. Versions for 4-, 5- and 6-bladed main rotor:

a) the cases with the blade tip speed of $190 \mathrm{~m} / \mathrm{s}$,

b) the cases with the blade tip speed of $220 \mathrm{~m} / \mathrm{s}$.
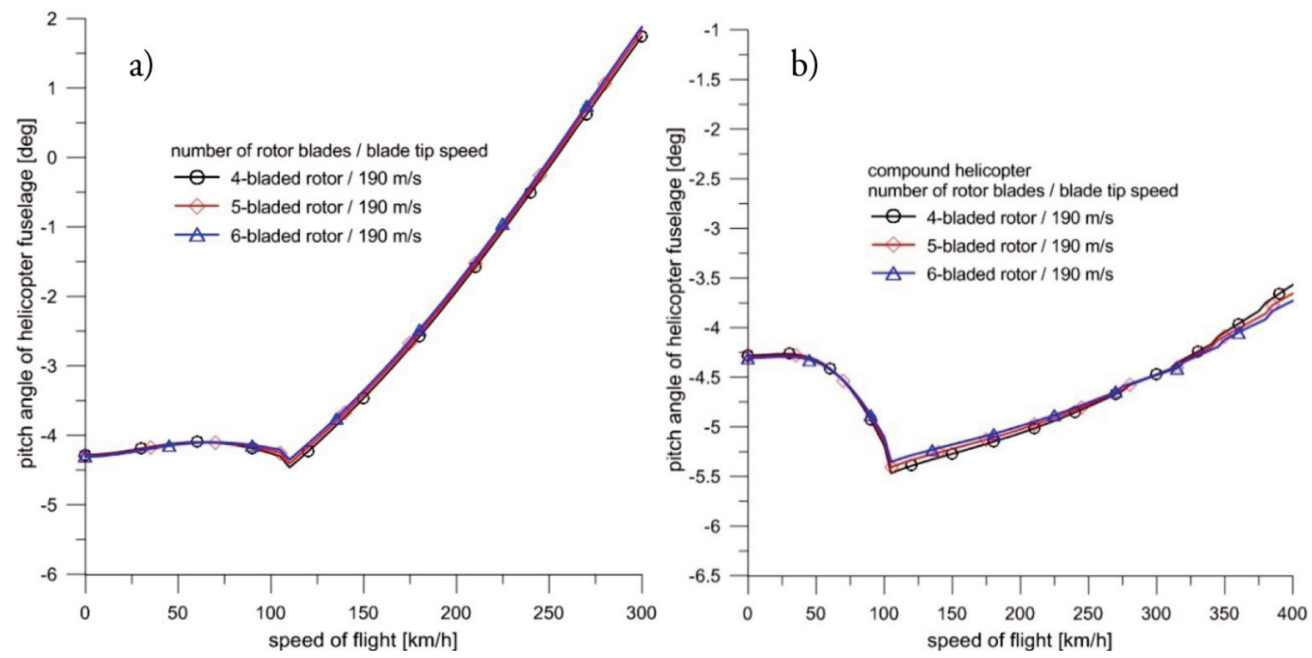

Fig. 10. The equilibrium pitch angle for fuselage of helicopter with take-off mass of $6,000 \mathrm{~kg}$ in level flight. Versions for 4-, 5- and 6-bladed main rotor with the blade tip speed of $190 \mathrm{~m} / \mathrm{s}$ :

a) the cases for conventional helicopter,

b) the cases for compound helicopter,

(+) for pitched down position of fuselage nose. 
Increase of flight speed of compound helicopter is possible due to the generation of enlarged thrust of the pusher propellers. Fig. 14 depicts the rapidly increasing with flight speed amount of power required to drive the pusher propellers, which reaches $1,800 \mathrm{~kW}$ for flight at speed of $400 \mathrm{~km} / \mathrm{h}$. For comparison the total power required for the helicopter flight in hover (Fig. 11a) is lower and equals 1,200 kW. While flight at speed of $400 \mathrm{~km} / \mathrm{h}$ requires higher total power equal to 2,900 kW in the case of a 6-bladed rotor with the blade tip speed of $190 \mathrm{~m} / \mathrm{s}$. In Fig. $11 \mathrm{~b}$ can be noticed that a helicopter with higher blade tip speed of $220 \mathrm{~m} / \mathrm{s}$ required total power is close to $4,000 \mathrm{~kW}$. Flying at speed over $300 \mathrm{~km} / \mathrm{h}$ is possible for level of power much more higher than required in the hover condition.
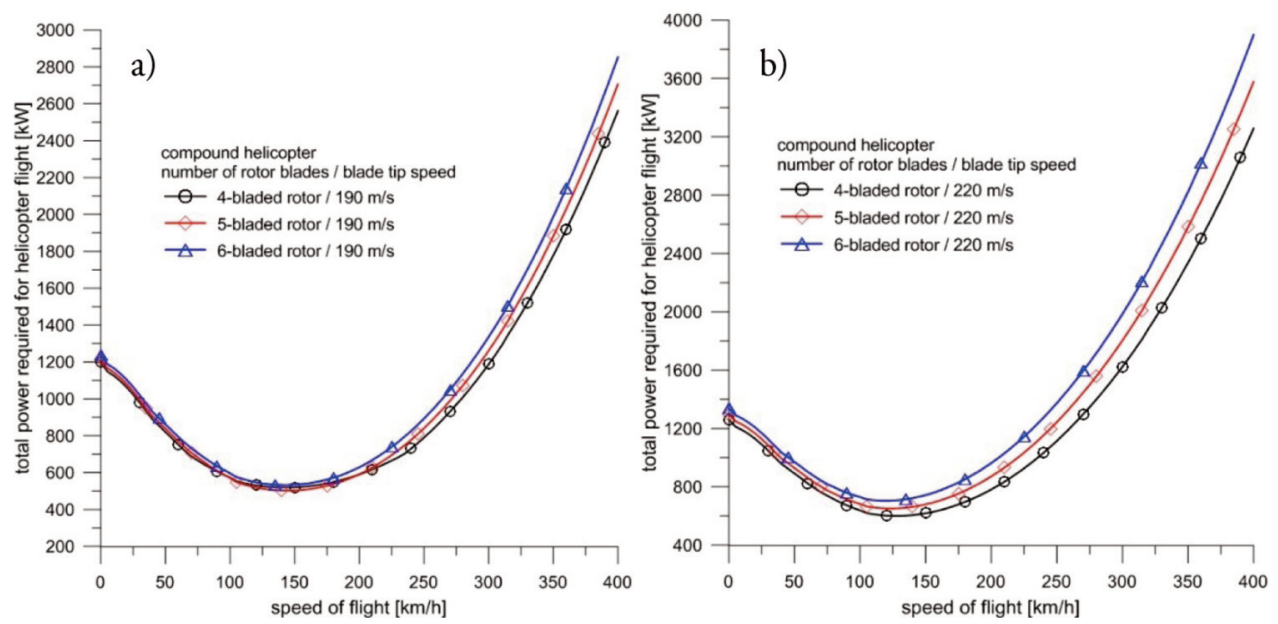

Fig. 11. Total power required for flight for compound helicopter with the take-off mass of $6,000 \mathrm{~kg}$, the versions for 4-, 5- and 6-bladed main rotor the cases with:

a) blade tip speed of $190 \mathrm{~m} / \mathrm{s}$,

b) blade tip speed of $220 \mathrm{~m} / \mathrm{s}$.
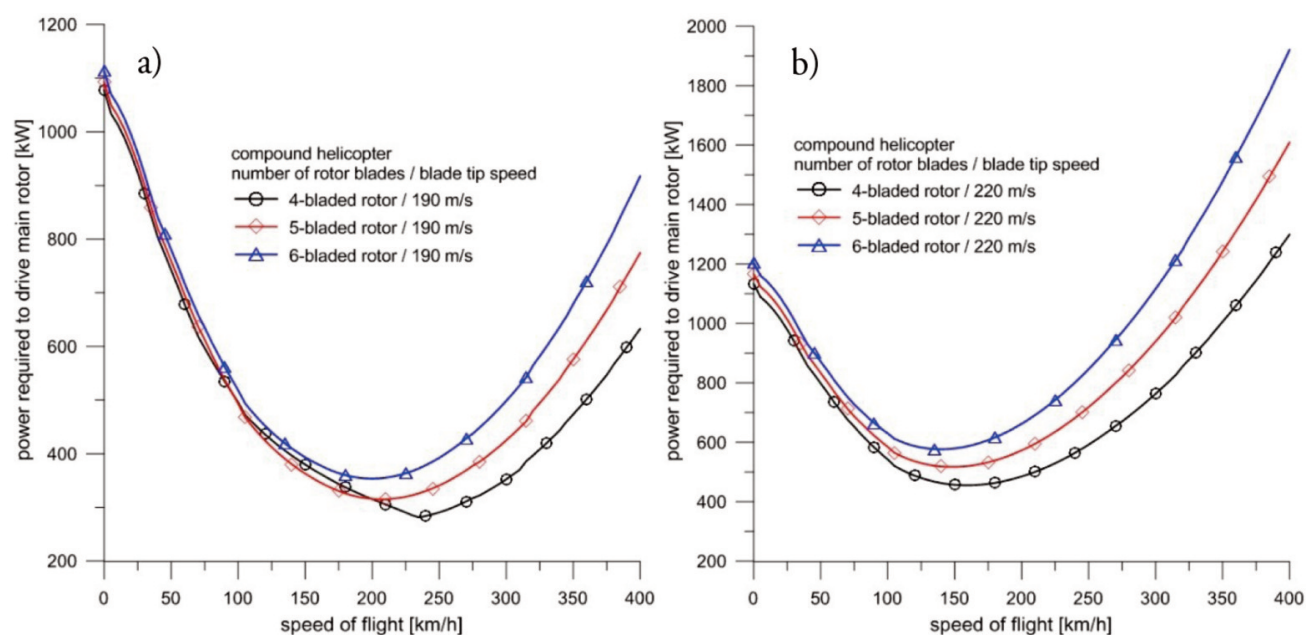

Fig. 12. Power required to drive the main rotor for compound helicopter with take-off mass of $6,000 \mathrm{~kg}$, the versions for 4-, 5- and 6-bladed main rotor:

a) the cases with blade tip speed of $190 \mathrm{~m} / \mathrm{s}$,

b) the cases with blade tip speed of $220 \mathrm{~m} / \mathrm{s}$. 
In the case of compound helicopter at the range of high speed the power required to drive the main rotor is higher for a 6-bladed rotor than for the 4-bladed one (Fig. 12). This effect can be explained by enlarged, in the case of a 4-bladed rotor, component of the airflow coming through rotor disk from the lower to upper surface of the rotor which is similar to the autorotation condition. In the case of a 4-bladed rotor at a single blade is generated higher thrust which causes the higher blade flapping position and prompts the growth of the out-of-plane airflow component.
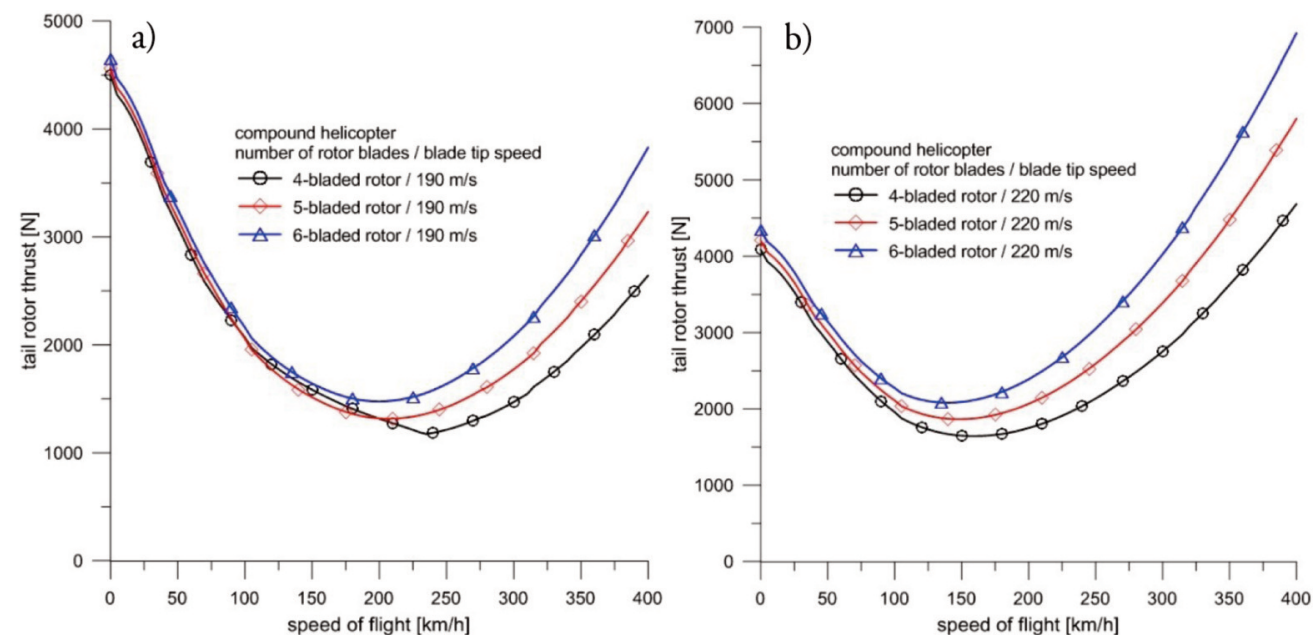

Fig. 13. Changes of tail rotor thrust due to flight speed for compound helicopter with the take-off mass of 6,000kg, the 4-, 5- and 6-bladed main rotor versions:

a) the cases with blade tip speed of $190 \mathrm{~m} / \mathrm{s}$,

b) the cases with blade tip speed of $220 \mathrm{~m} / \mathrm{s}$.

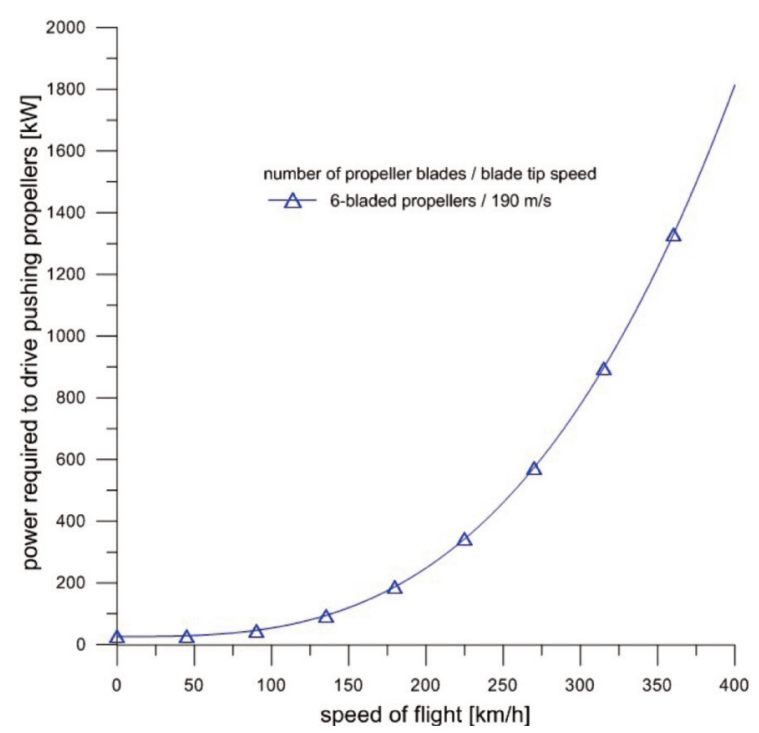

Fig. 14. Changes of power required to drive the pushing propellers due to flight speed for compound helicopter with the take-off mass of $6,000 \mathrm{~kg}$. 
Application of wings to the compound helicopter gives a higher ratio of the rotor offload with the increase of flight speed (Tab. 1).

Tab. 1. Main rotor offload due to flight speed for compound helicopter with mass of $6,000 \mathrm{~kg}$.

\begin{tabular}{|l|c|c|c|}
\hline flight speed $[\mathrm{km} / \mathrm{h}]$ & 250 & 325 & 400 \\
\hline lift of wing $[\mathrm{N}]$ & 18,440 & 29,810 & 42,050 \\
\hline rotor offload [\%] & 31.3 & 50.6 & 71,4 \\
\hline
\end{tabular}
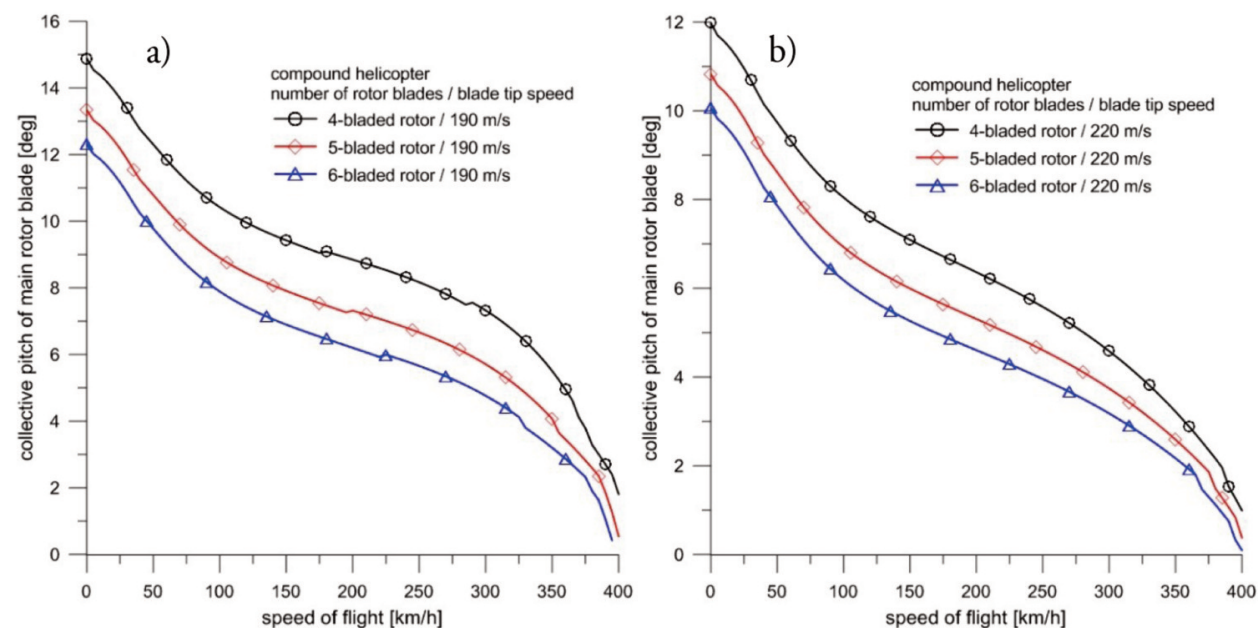

Fig. 15. Change of the collective pitch of the main rotor blades for a compound helicopter with pusher propellers and additional wings in conditions of level flight. Helicopter take-off mass of $6,000 \mathrm{~kg}$.

Versions of 4-, 5- and 6-bladed main rotor, the cases with:

a) blade tip speed of $190 \mathrm{~m} / \mathrm{s}$,

b) blade tip speed of $220 \mathrm{~m} / \mathrm{s}$.
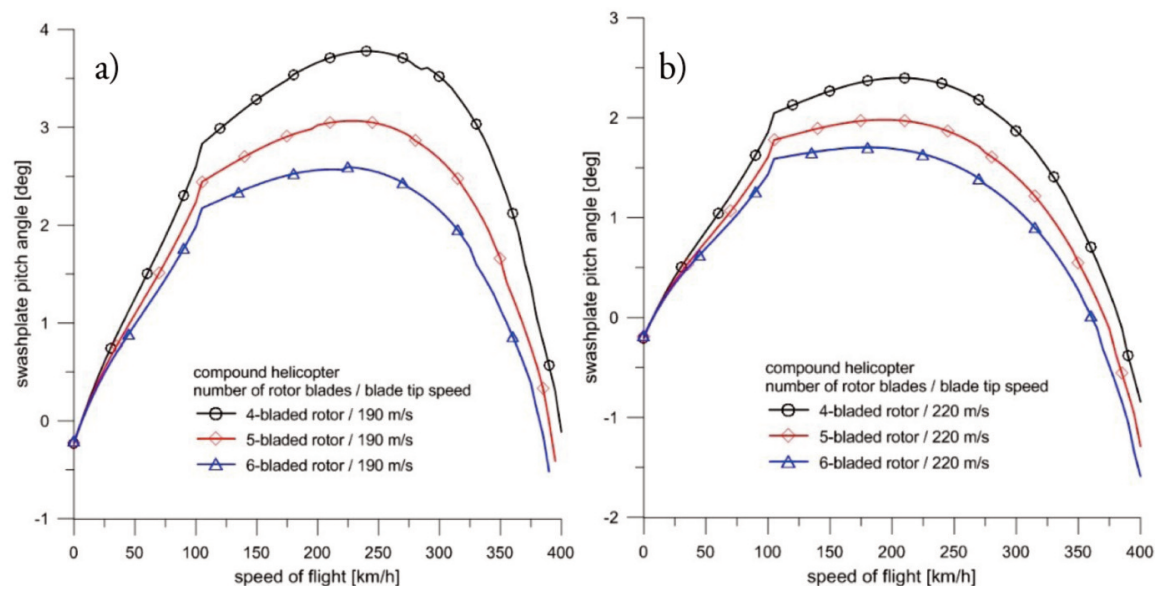

Fig. 16. Changes of the swashplate pitch angle for a compound helicopter with the take-off mass of $6,000 \mathrm{~kg}$ in the level flight conditions. Versions for a 4-, 5- and 6-bladed main rotor, the cases with:

a) blade tip speed of $190 \mathrm{~m} / \mathrm{s}$,

b) blade tip speed of $220 \mathrm{~m} / \mathrm{s}$. 
The lower participation of rotor in generation of the total lift with increasing flight speed is shown in Fig. 17b. Beside the pusher propellers, part of the propulsive force can be provided by horizontal component of the rotor thrust (Fig. 17a). Rotor offload at high speed of flight allows for lower value of the collective pitch of the main rotor blades (Fig. 15) and lower pitch angle of swashplate position (Fig. 16).
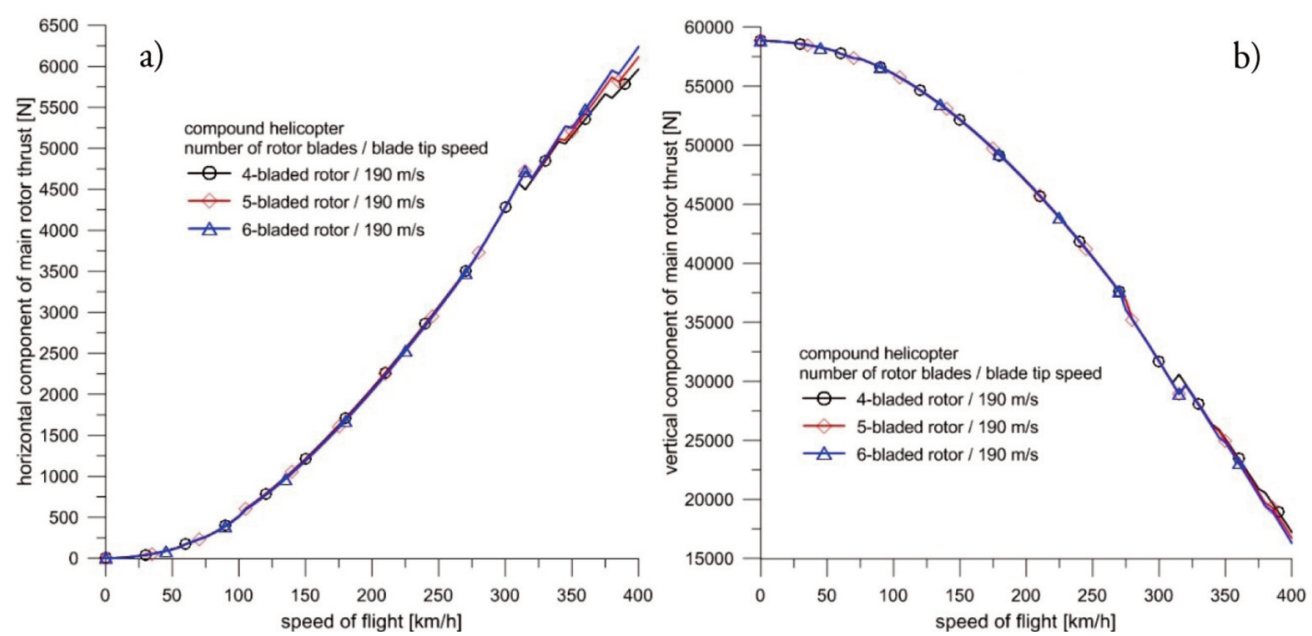

Fig. 17. Horizontal and vertical components of the main rotor thrust for a compound helicopter with the take-off mass of 6,000kg in level flight conditions. Versions of a 4-, 5- and 6-bladed main rotor:

a) horizontal component of the main rotor thrust,

b) vertical component of the main rotor thrust.

The more detailed model of an elastic rotor blade was applied for calculations of rotor loads and blade deflections for conventional and compound configurations of helicopter for defined equilibrium conditions at flight speed of $250 \mathrm{~km} / \mathrm{h}$. At greater flight speed of $325 \mathrm{~km} / \mathrm{h}$ and $400 \mathrm{~km} / \mathrm{h}$ the calculations were performed only for compound helicopter.

In Fig. 18 are shown plots of the blade torsion deflections at the blade tip and in Fig. 20 plots of the bending out-of-plane deflections in level flight at speed of $250 \mathrm{~km} / \mathrm{h}$ for cases of soft version blades (Tab. 2) of 4-, 5-, 6-bladed rotor.

Tab. 2. Eigen mode frequencies for soft and stiff versions of rotor blade.

\begin{tabular}{|l|c|c|c|c|c|c|c|c|}
\hline \multirow{2}{*}{$\begin{array}{l}\text { Version of } \\
\text { rotor blade }\end{array}$} & \multicolumn{7}{|c|}{ Rotor blade frequency $[\mathrm{v} / \omega]$} \\
\cline { 2 - 10 } & F0 & F1 & F2 & F3 & C0 & C1 & T0 & T1 \\
\hline soft & 1.013 & 2.551 & 4.376 & 7.319 & 0.287 & 4.369 & 5.232 & 12.507 \\
\hline stiff & 1.013 & 2.819 & 5.801 & 10.069 & 0.287 & 5.869 & 9.163 & 15.813 \\
\hline
\end{tabular}

For calculations concerning rotor loads and blade deformations in chosen flight states there were introduced data of blade eigen modes and frequencies. The values of the considered mode frequencies for soft and stiff versions of rotor blade are collected in Tab. 2. Symbols used in Tab. 2 to sign blade eigen modes are as follows: $\mathrm{F}$ - out-of-plane bending mode, $\mathrm{C}$ - in-plane bending mode, $\mathrm{T}$ - torsion mode, digits after mode symbol are equal to the number of nodes. The frequency values are related to the rotational speed of rotor for the case of blade tip speed of $190 \mathrm{~m} / \mathrm{s}$. 
Comparing time-runs of the blade torsion deflections, the highest values of the blade twist are noticed at the retreating blade position (azimuth $270^{\circ}$ ). For the 6-bladed rotor of conventional helicopter the blade tip torsion deflection exceeds $6^{\circ}$ (Fig. 18a), while for offloaded rotor blade of a compound helicopter torsion deflection is limited to $3^{\circ}$ (Fig. 18b). Similarly to torsion deflections, the lesser values of control moments of the blade pitch during a rotor revolution can be observed for a compound helicopter (Fig. 19).
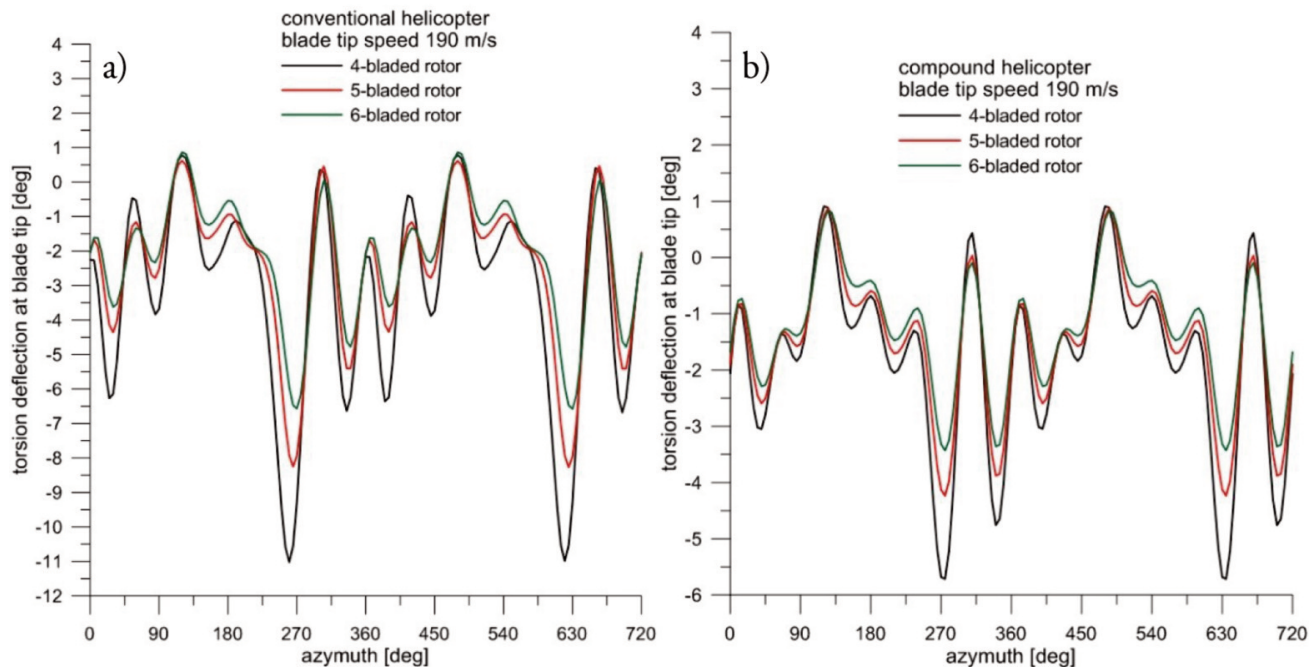

Fig. 18. Time-runs of torsion deflection at blade tip during rotor revolutions in level flight at speed of $250 \mathrm{~km} / \mathrm{h}$. The cases of soft version blades for a 4-, 5-, 6-bladed rotor with blade tip speed of $190 \mathrm{~m} / \mathrm{s}$ :

a) conventional helicopter,

b) compound helicopter.
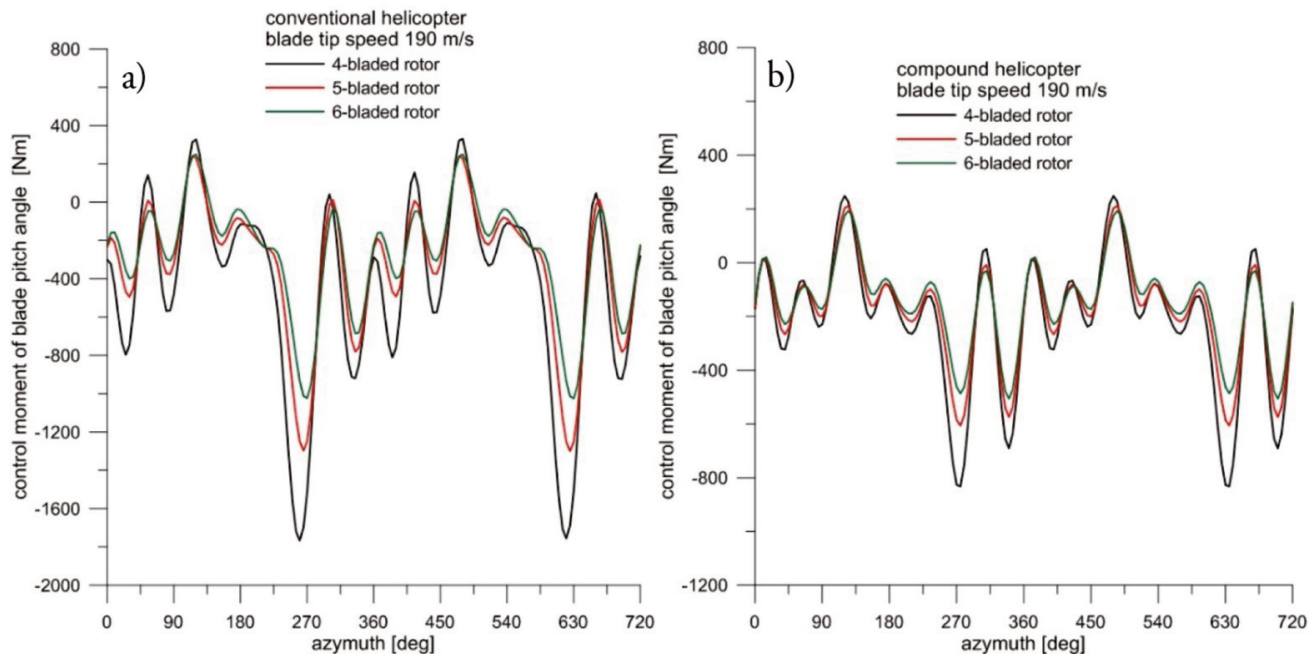

Fig. 19. Control moments of blade pitch angle during rotor revolutions in level flight at speed of $250 \mathrm{~km} / \mathrm{h}$. The cases of soft version blades for a 4-, 5-, 6-bladed rotor with blade tip speed of $190 \mathrm{~m} / \mathrm{s}$ :

a) conventional helicopter,

b) compound helicopter. 
At the same flight speed of $250 \mathrm{~km} / \mathrm{h}$ in the case of compound helicopter with offloaded rotor the bending out-of-plane deflection at blade tip for the 6 -bladed rotor reaches value of $0.8 \mathrm{~m}$, while for the conventional configuration maximum bending deflection is about $1.2 \mathrm{~m}$ (Fig. 20).
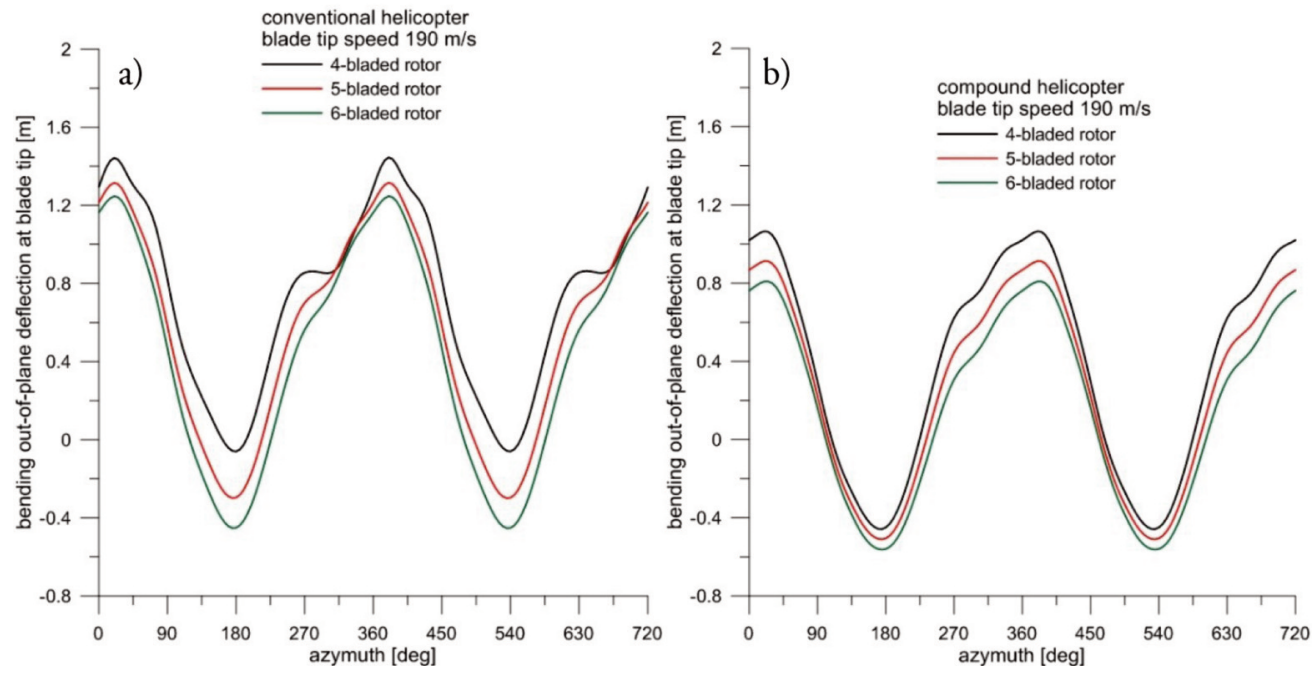

Fig. 20. Bending out-of-plane deflection at blade tip during rotor revolutions in level flight at speed of $250 \mathrm{~km} / \mathrm{h}$. The cases of soft version blades for 4-, 5-, 6-bladed rotor with blade tip speed of $190 \mathrm{~m} / \mathrm{s}$ :

a) conventional helicopter,

b) compound helicopter.
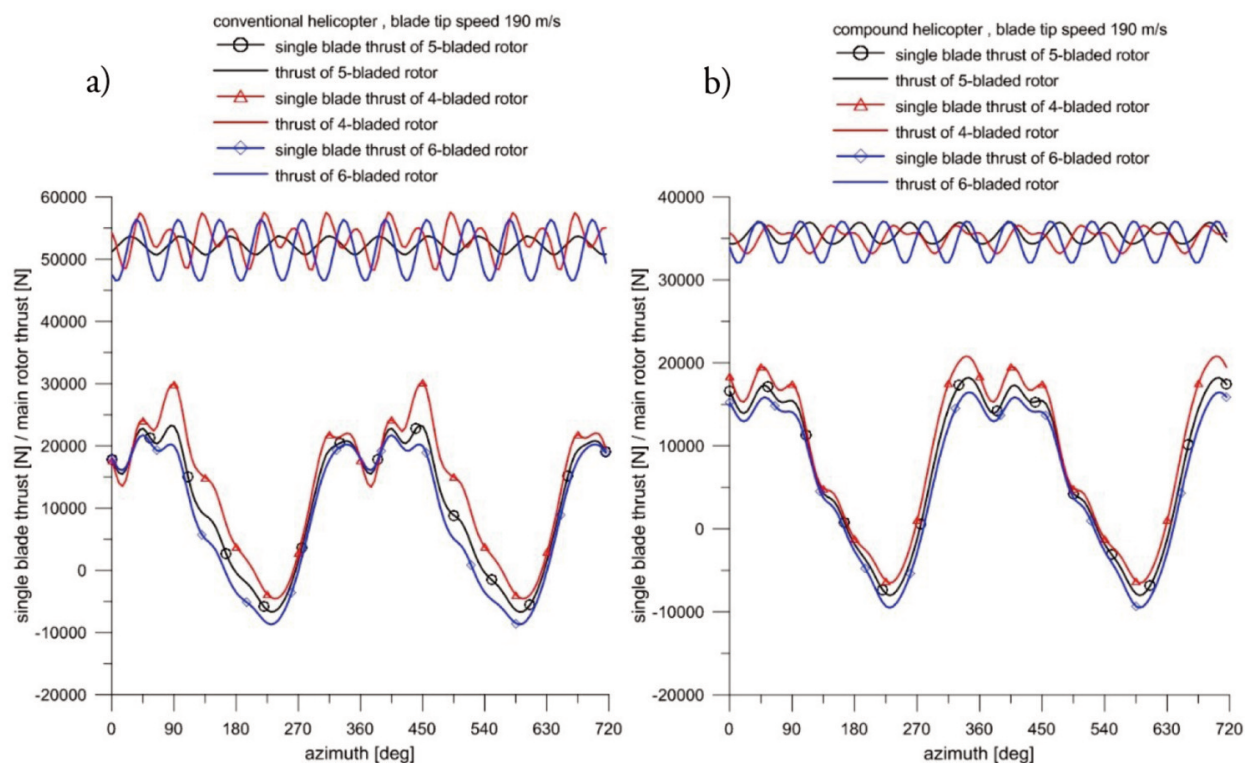

Fig. 21. Single blade thrust and main rotor thrust during two rotor revolutions in level flight at speed of $250 \mathrm{~km} / \mathrm{h}$. The cases of soft blades for 4-, 5-, 6-bladed rotor with blade tip speed of $190 \mathrm{~m} / \mathrm{s}$ :

a) conventional helicopter,

b) compound helicopter. 
Offloaded rotor for compound helicopter enables diminishing amplitude of time-run of the single blade thrust and the total rotor thrust in level flight at speed of $250 \mathrm{~km} / \mathrm{h}$ (Fig. 21). For considered variant of soft rotor blades amplitudes of the single blade thrust and amplitudes of rotor thrust sharply grow with increase of flight speed (Fig. 22). At flight speed of $400 \mathrm{~km} / \mathrm{h}$, despite offloaded rotor, the amplitude of rotor thrust increases to about 7,500 N (Fig. 22b).

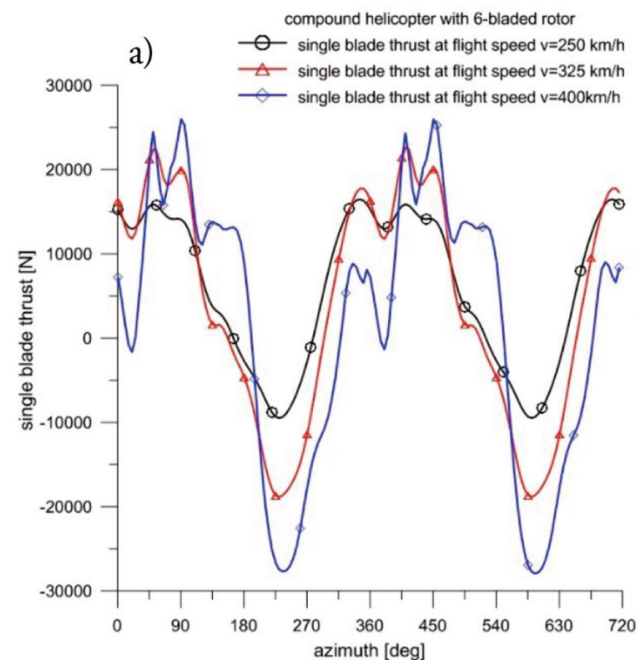

b)

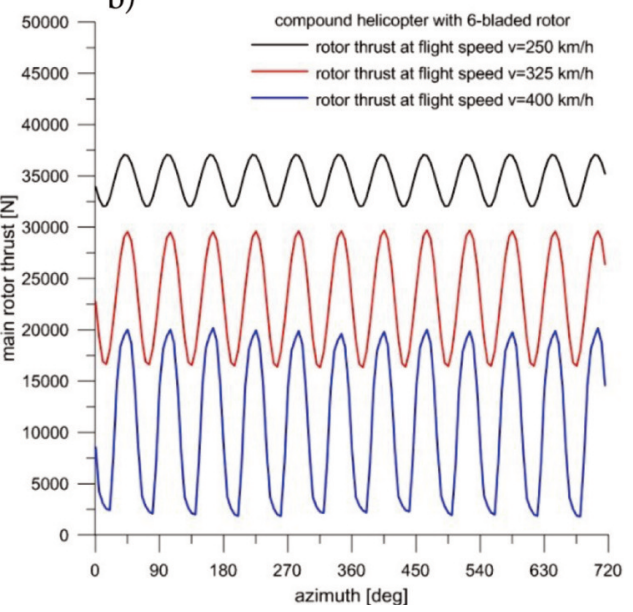

Fig. 22. Single blade thrust and main rotor thrust during two rotor revolutions in level flight at speed of $250 \mathrm{~km} / \mathrm{h}, 325 \mathrm{~km} / \mathrm{h}$ and $400 \mathrm{~km} / \mathrm{h}$. The case of compound helicopter with a 6-bladed rotor and blade tip speed of $190 \mathrm{~m} / \mathrm{s}$, variant of soft blades: a) single blade thrust, b) main rotor thrust.
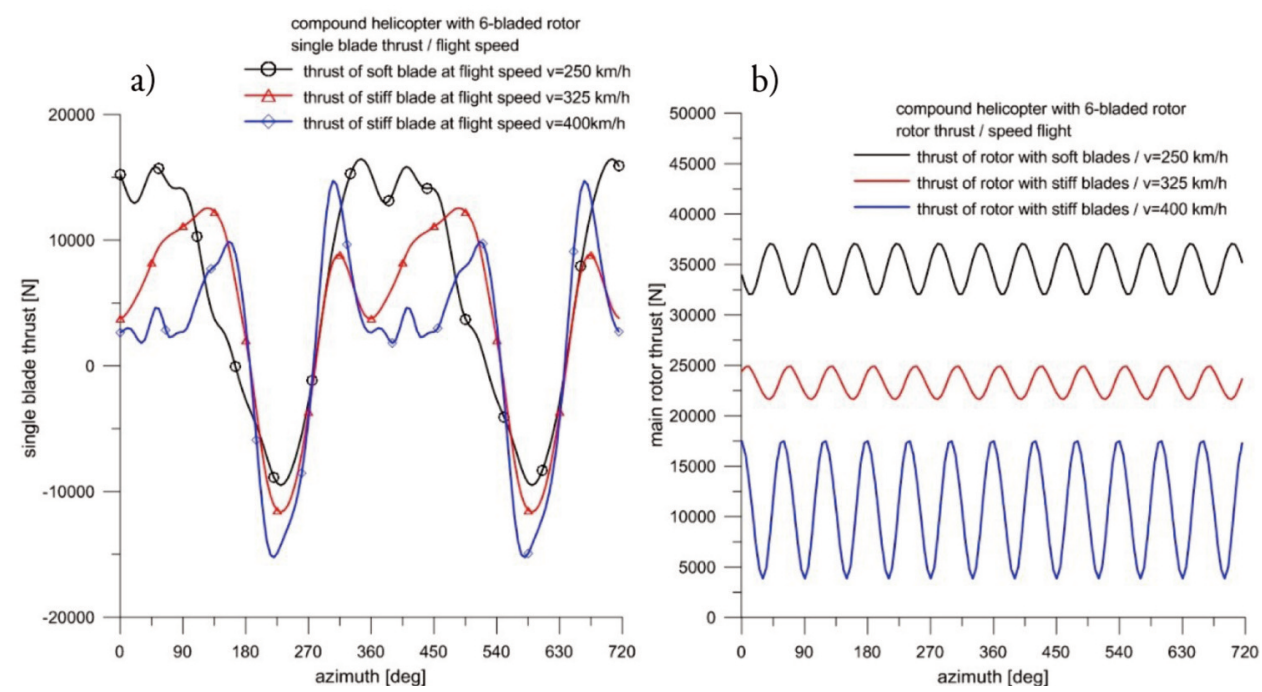

Fig. 23. Single blade thrust and main rotor thrust during rotor revolutions in level flight at speed of $250 \mathrm{~km} / \mathrm{h}$ for rotor with soft blades and at speed $325 \mathrm{~km} / \mathrm{h}$ and $400 \mathrm{~km} / \mathrm{h}$ for rotor with stiff blades. The case of compound helicopter with a 6-bladed rotor and blade tip speed of $190 \mathrm{~m} / \mathrm{s}$ : a) single blade thrust, b) main rotor thrust. 
Application of rotor with stiff blades (Tab. 2) allows to reduce the growth rate of rotor thrust amplitude with increasing flight speed (Fig. 23). In Fig. 24 is shown comparison of torsion deflection time-runs for the cases of soft- and stiff-bladed rotors for compound helicopter at flight speed of 250, 325 and $400 \mathrm{~km} / \mathrm{h}$. Torsion deflections at the blade tip for stiff-bladed rotor at flight speed of $400 \mathrm{~km} / \mathrm{h}$ are in scope between $0.5^{\circ}$ and $-1.5^{\circ}$. In the case of stiff-bladed rotor reduction of blade deflections affects diminishing of the blade control moment (Fig. 25).
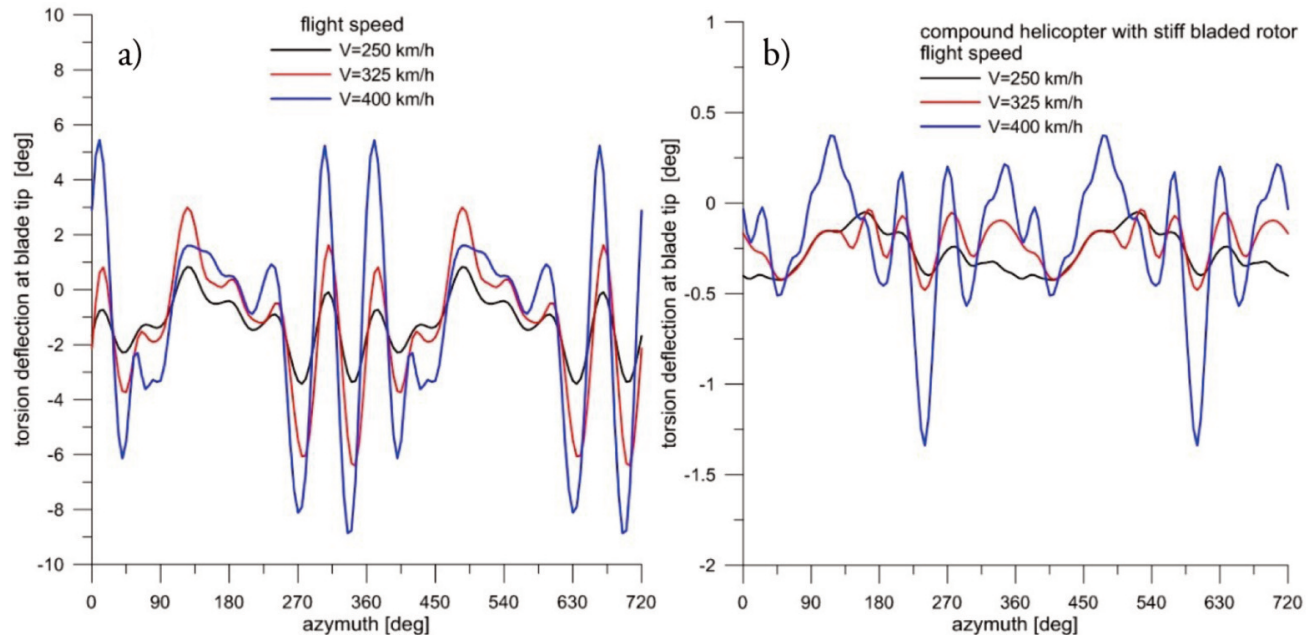

Fig. 24. Torsion deflection at blade tip during rotor revolutions in level flight at speed of $250 \mathrm{~km} / \mathrm{h}, 325 \mathrm{~km} / \mathrm{h}$ and $400 \mathrm{~km} / \mathrm{h}$. Compound helicopter with 6-bladed rotor and blade tip speed of $190 \mathrm{~m} / \mathrm{s}$ : a)case for soft blades, b)case for stiff blades.
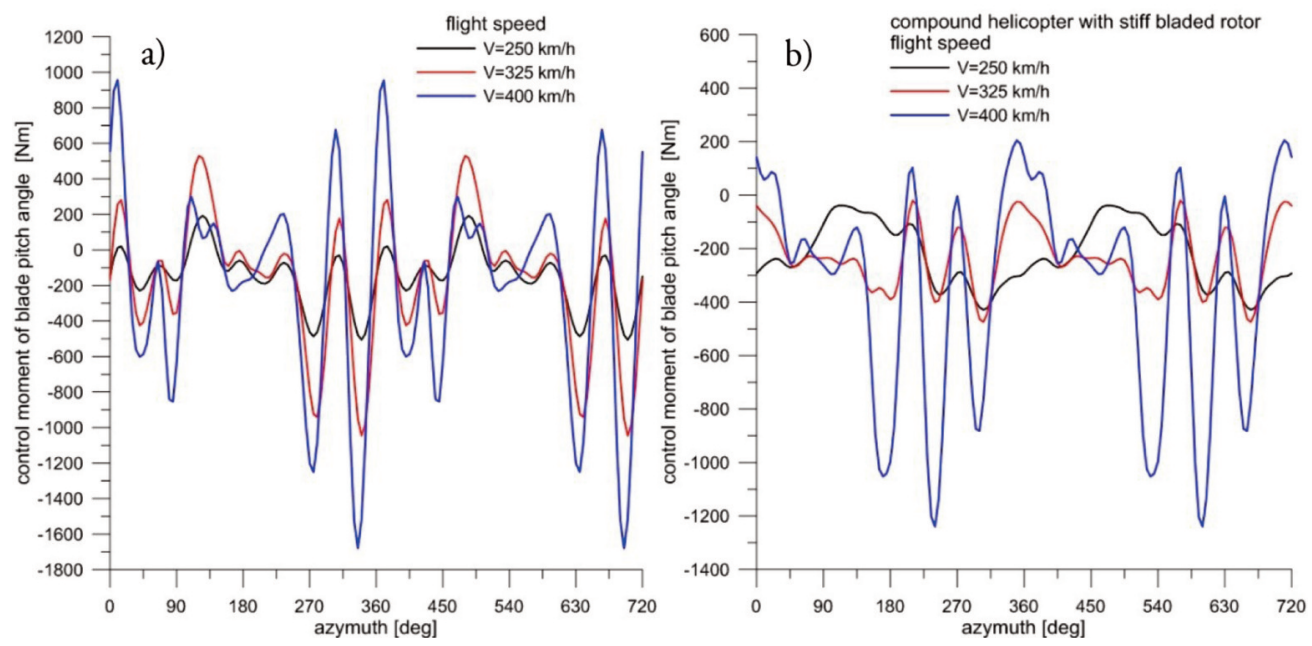

Fig. 25. Blade control moment during rotor revolutions in level flight at speed of $250 \mathrm{~km} / \mathrm{h}, 325 \mathrm{~km} / \mathrm{h}$ and $400 \mathrm{~km} / \mathrm{h}$. The case of compound helicopter with a 6-bladed rotor and blade tip speed of $190 \mathrm{~m} / \mathrm{s}$ : a) case for soft blades, b) case for stiff blades.

Range of bending out-of-plane deflections for stiff-bladed rotor is also reduced but due to articulated blade-rotor hub connection oscillates between $-0.7 \mathrm{~m}$ and $0.9 \mathrm{~m}$ (Fig. 26). 

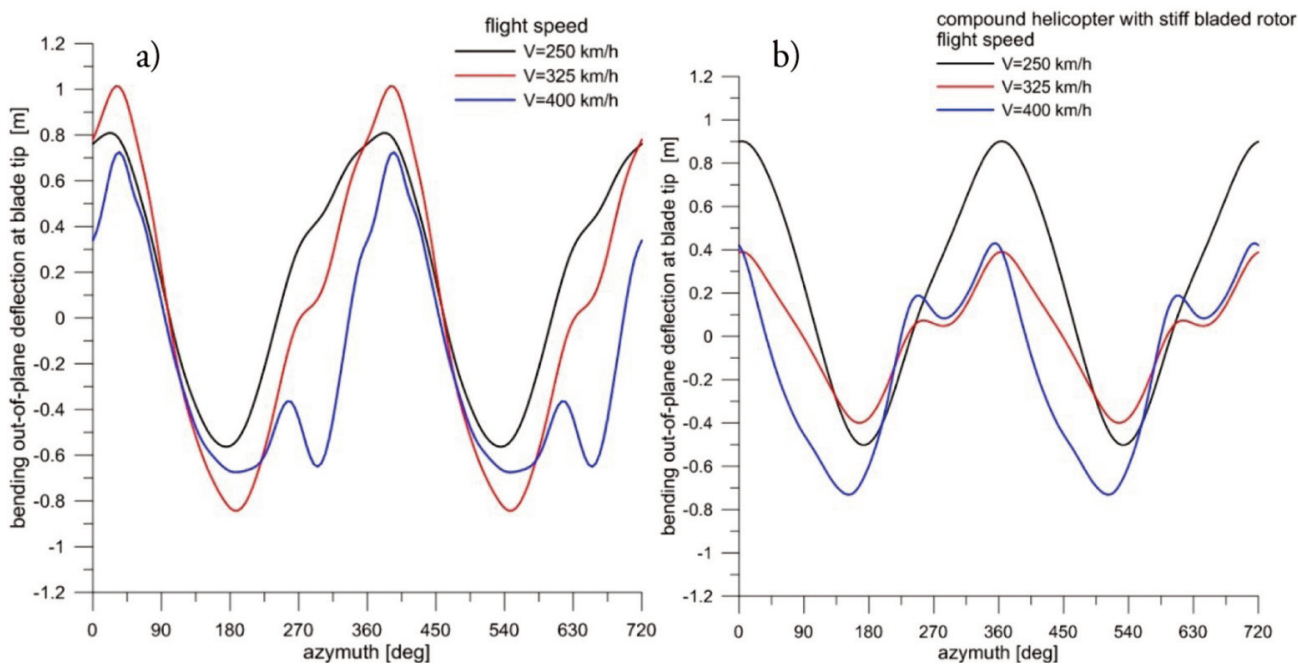

Fig. 26. Bending out-of-plane deflection at blade tip in level flight at speed of $250 \mathrm{~km} / \mathrm{h}, 325 \mathrm{~km} / \mathrm{h}$ and $400 \mathrm{~km} / \mathrm{h}$. The case of compound helicopter with 6-bladed rotor and blade tip speed of $190 \mathrm{~m} / \mathrm{s}$ :

a) case for soft blades, b) case for stiff blades.

Details of the blade behavior for a compound helicopter while increasing flight speed are shown in plots of rotor disk distributions of the following blade parameters: torsion deflection, bending out-of-plane deflection and local attack angles (Fig. 27-29). For the case of a stiff-bladed rotor at the high speed conditions the range of oscillations of the blade torsion deflection is limited to $-2^{\circ}$ (Fig. 27). Observed in rotor disk the number of cycles of torsion deformations is correlated with frequency of the first eigen mode of blade torsion vibration. In disk distributions of the blade out-of-plane deflection the lower position of the blade tip relative to rotation plane can be noticed at the fore part of the rotor in vicinity of azimuth $180^{\circ}$ and higher blade position at the aft part of the rotor near azimuth $0^{\circ}$ (Fig. 28).
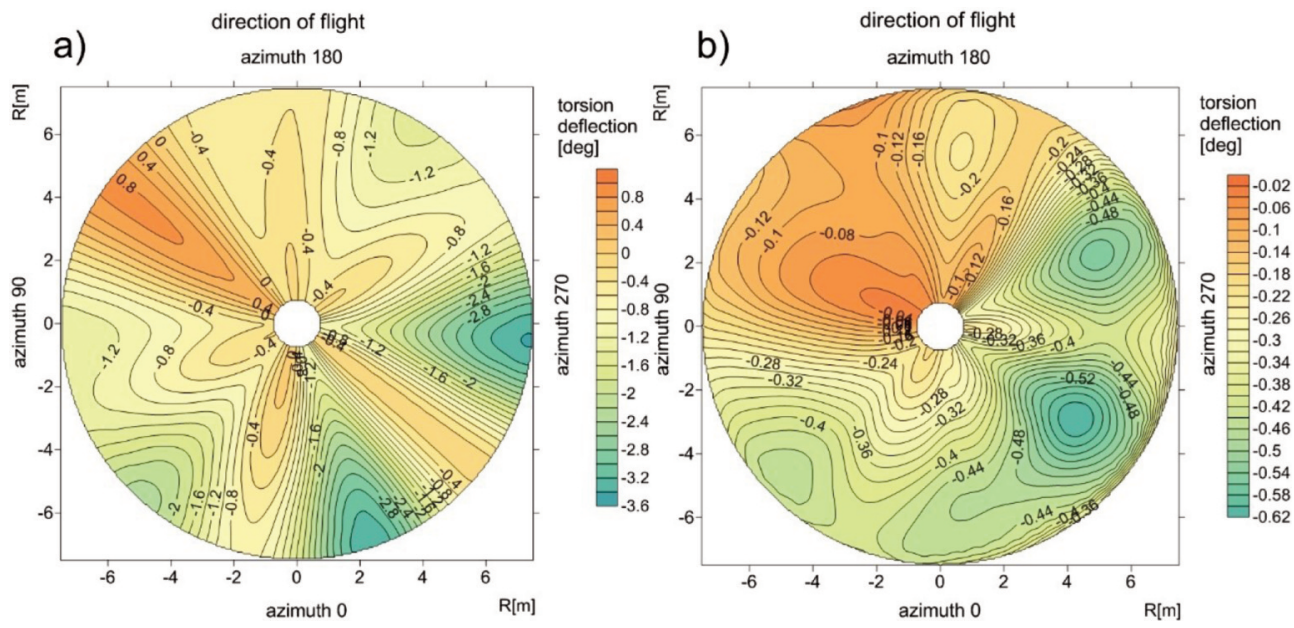

Fig. 27. Rotor disk distribution of blade torsion deformation for compound helicopter with a 6-bladed main rotor and with blade tip speed of $190 \mathrm{~m} / \mathrm{s}$ :

a) the case of soft blades in level flight at speed of $250 \mathrm{~km} / \mathrm{h}$,

b) the case of stiff blades in level flight at speed of $250 \mathrm{~km} / \mathrm{h}$, 

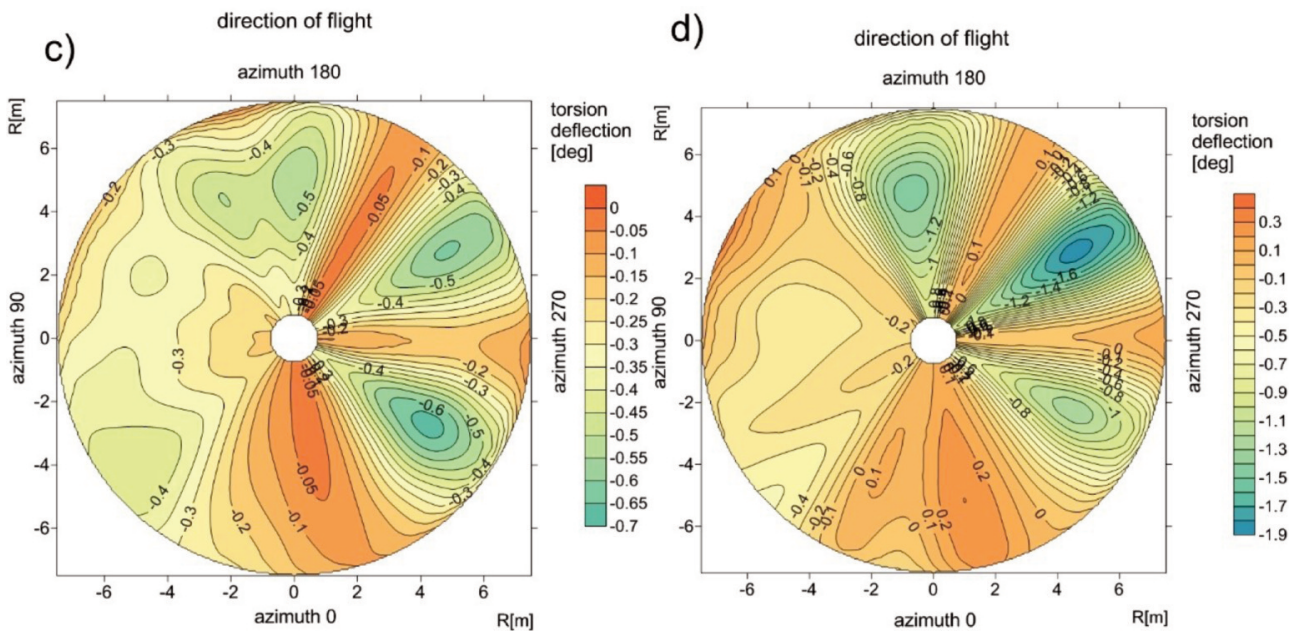

Fig. 27. Rotor disk distribution of blade torsion deformation for compound helicopter with a 6-bladed main rotor and with blade tip speed of $190 \mathrm{~m} / \mathrm{s}$ : c) the case of stiff blades in level flight at speed of $325 \mathrm{~km} / \mathrm{h}$, d) the case of stiff blades in level flight at speed of $400 \mathrm{~km} / \mathrm{h}$.

a)

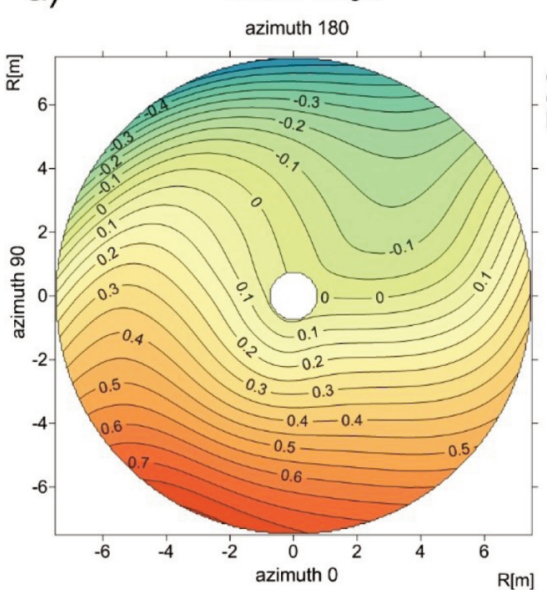

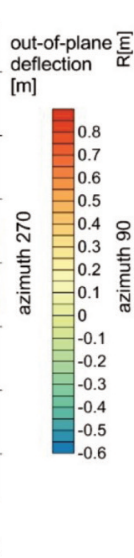

b) direction of flight

azimuth 180

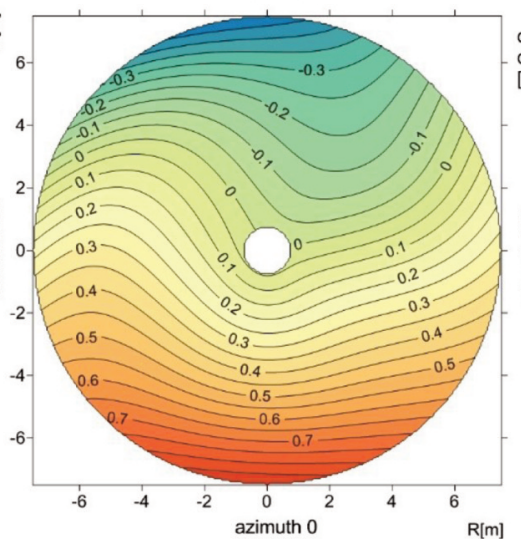

out-of-plane deflection $[\mathrm{m}]$

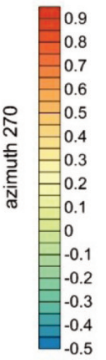

Fig. 28. Rotor disk distribution of blade out-of-plane bending deformation for compound helicopter with a 6-bladed main rotor and blade tip speed of $190 \mathrm{~m} / \mathrm{s}$ :

a) the case of soft blades in level flight at speed of $250 \mathrm{~km} / \mathrm{h}$,

b) the case of stiff blades in level flight at speed of $250 \mathrm{~km} / \mathrm{h}$, 
c)

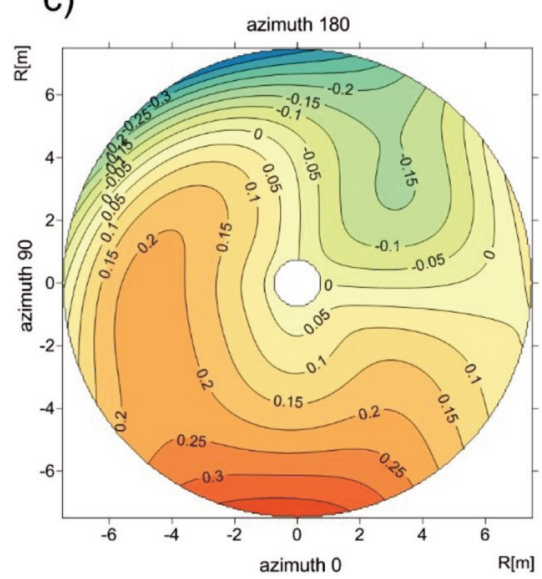

d)

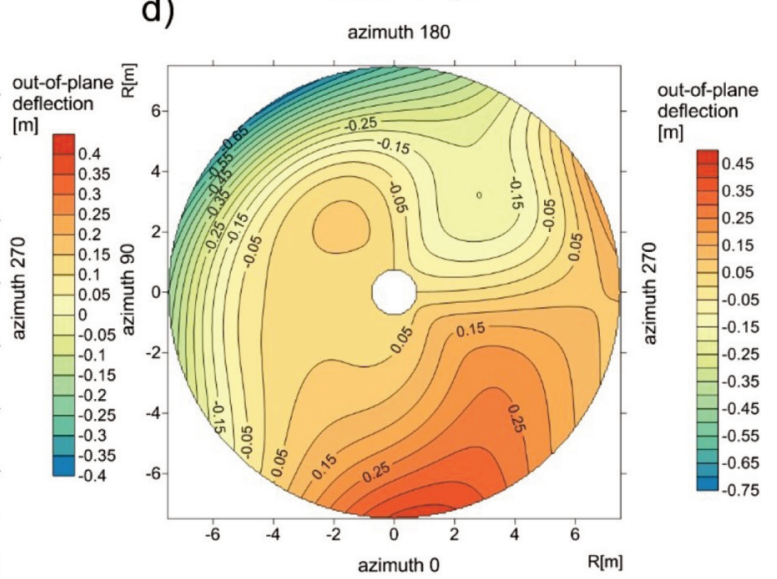

Fig. 28. Rotor disk distribution of blade out-of-plane bending deformation for compound helicopter with a 6-bladed main rotor and blade tip speed of $190 \mathrm{~m} / \mathrm{s}$ :

c) the case of stiff blades in level flight at speed of $325 \mathrm{~km} / \mathrm{h}$,

d) the case of stiff blades in level flight at speed of $400 \mathrm{~km} / \mathrm{h}$.

In the case of a compound helicopter at high speed flight with offloaded rotor, the enlarged zone of the negative local angle of attack is observed, extending at the blade tip cross-sections from the fore azimuth of $180^{\circ}$ to nearly retreating blade position at azimuth of $300^{\circ}$ (Fig. 29). Additional feature of the attack angle disk distribution at high speed flight is the growing area of inverted airflow at the blade root for azimuth in vicinity of the retreating blade position.
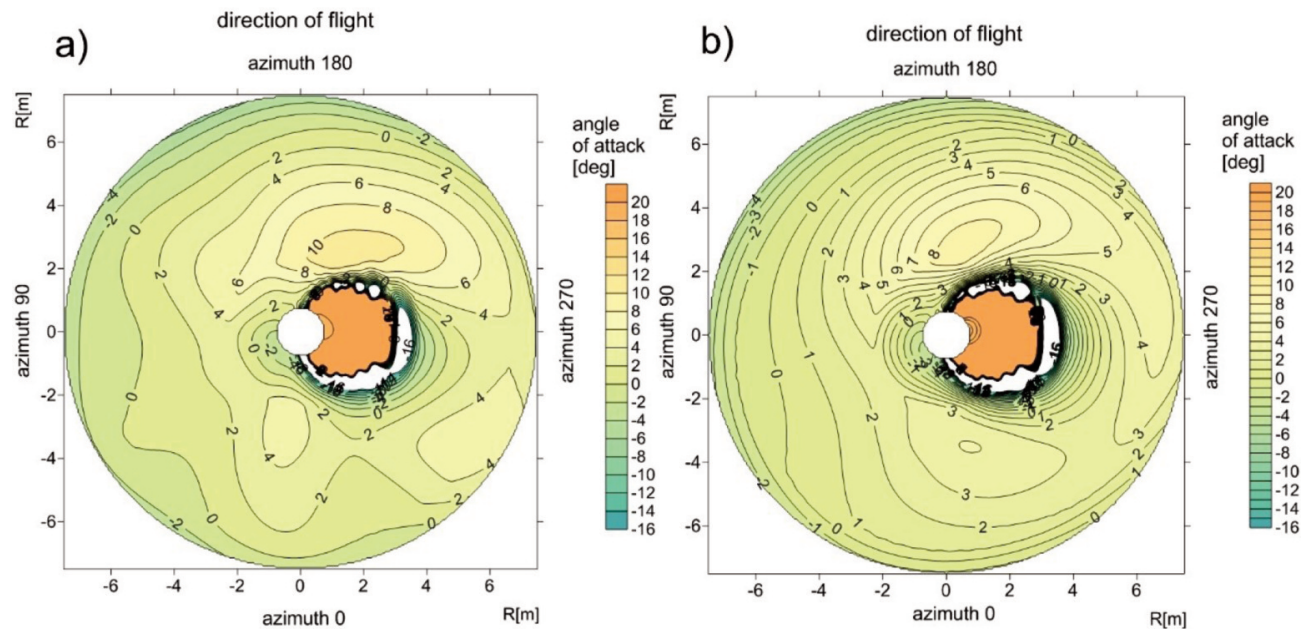

Fig. 29. Rotor disk distribution of blade local attack angle for compound helicopter with 6-bladed main rotor and blade tip speed of $190 \mathrm{~m} / \mathrm{s}$ :

a) the case of soft blades in level flight at speed of $250 \mathrm{~km} / \mathrm{h}$,

b) the case of stiff blades in level flight at speed of $250 \mathrm{~km} / \mathrm{h}$, 

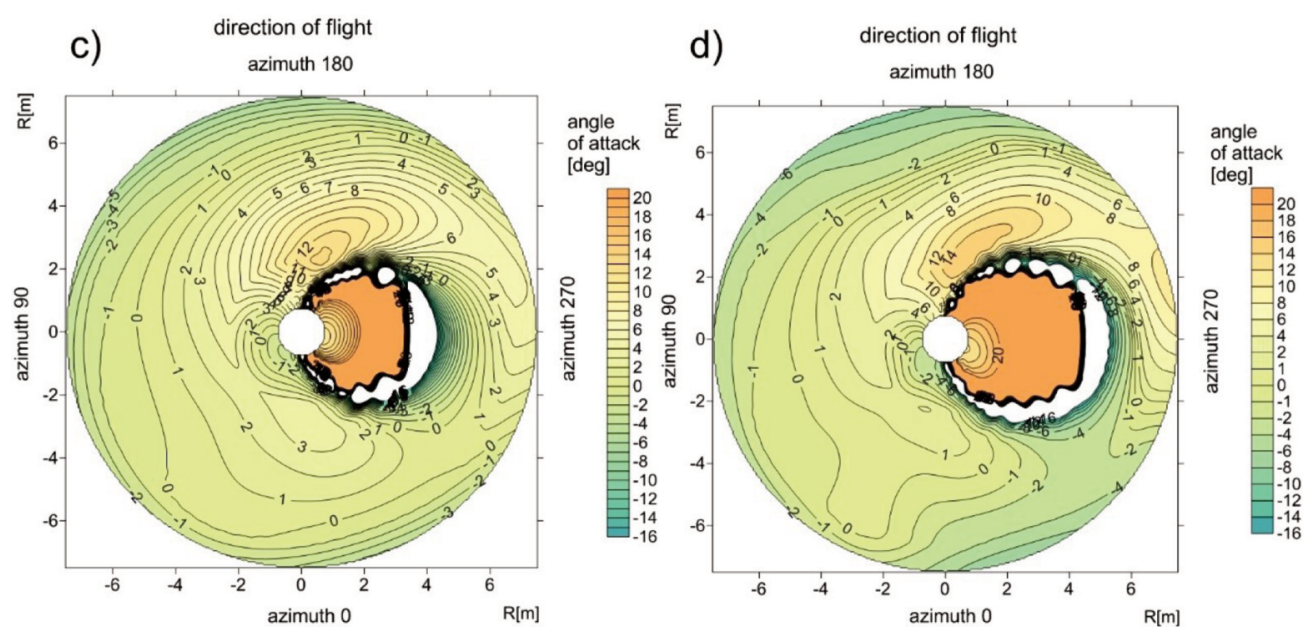

Fig. 29. Rotor disk distribution of blade local attack angle for compound helicopter with 6-bladed main rotor and blade tip speed of $190 \mathrm{~m} / \mathrm{s}$ :

c) the case of stiff blades in level flight at speed of $325 \mathrm{~km} / \mathrm{h}$,

d) the case of stiff blades in level flight at speed of $400 \mathrm{~km} / \mathrm{h}$.

\section{CONCLUSIONS}

The simulation calculations help to define conditions which enable to achieve the range of high speed flights and to enlarge operational envelope of the compound helicopter equipped with articulated main rotor. Reaching the range of high speed flights requires installation of the high power units to drive the pusher propellers which allow to generate enough propulsive force to overcome the rising aerodynamic drag of the rotorcraft. At high speed flights reduction of excessive vibration level can be achieved by properly applied stiffness of the blades, increased number of the rotor blades and reduced blade tip speed. Introduction of wings and additional pusher propellers to a compound helicopter with the articulated rotor hub allows to reach higher speed of flight in comparison to conventional configuration of the rotorcraft.

\section{REFERENCES}

[1] https://www.helis.com/50s/rotodyne.php/ [access 2020-05-30].

[2] Robb, R.L., 2006, "Hybrid helicopters: compounding the quest for speed", Vertiflite, 52(6), pp. 30-56.

[3] Forman, B., 1996, "What killed the Cheyenne?", Vertiflite, 42(3), pp. 22-27.

[4] Gordon, Y., Komissarov, D. and Komissarov, S., 2005, "Mil's Heavylift Helicopters", Midland Publishing, England.

[5] http://www.chinook-helicopter.com/history/aircraft?A_Models/65-07992/65-07992.html/ [access 2020-05-31].

[6] https://www.museehelico-alat.com/visite-virtuelle/10-gazelle-sa-349/Les amis du musee de I'ALAT et de l'helicoptere-Gazelle SA 349 Prototype/ [access 2020-05-31].

[7] Hirschberg M., 2010, “X2, X3, S-97, and X-49: The Battle of the Compounds is Joined”, Vertiflite 56(4), pp. 16-22.

[8] Morgała M., 1981, "Polskie samoloty wojskowe 1945-1980”, (Eng.:"Polish Military Aircraft 19451980”), Wydawnictwo MON, Warszawa, pp. 210-211 (in Polish). 
[9] Roman, K., 2008, "Śmigłowce eksperymentalne - latające laboratoria na bazie śmigłowca IS-2", (Eng.:"Experimental helicopters - flying laboratories on the base of IS-2 helicopter"), Transactions of the Institute of Aviation, 194-195, pp. 295-302 (in Polish).

[10] Parsons, D., 2020, “U.S.Army taps Sikorsky Raider X, Bell Invictus for FARA fly-off”, Vertical Valor Magazine, Spring Issue 2020, p. 16.

[11] Parsons, D., 2020, “ Bell's Valor, Sikorsky/Boeing Defiant Advance in U.S.Army Future Assault Aircraft program”, Vertical Valor Magazine, Spring Issue 2020, p. 20-21.

[12] https://www.ainonline.com/aviation-news/defence/2016-01-06/modified-mi-24-explores-highspeed-helicopter-technology/ [access 2020-06-01].

[13] https://www.globalsecurity.org/military/world/russia/mi-x1.htm/ [access 2020-06-01].

[14] https://en.wikipedia.org/wiki/Kamov_Ka-92/ [access 2020-06-01].

[15] https:/www.flightglobal.com/helicopters/airbus-helicopters-maintains-racers-pace-despitedelays/137838.article/ [access 2020-06-02].

[16] Deal, P.L. and Jenkins, J.L.Jr., 1968, "Flight Investigation of the Wing-Rotor Lift-Sharing Characteristics of a Hingeless Rotor Compound Helicopter", 24th Annual National Forum of the American Helicopter Society, Washington, May 8-10.

[17] Jenkins, J.L.Jr. and Perry, L.D., 1970, "Investigation on Level-Flight and Maneuvering Characteristics of a Hingeless-Rotor Compound Helicopter", NASA TN D-5602, Washington.

[18] Erickson, R.E., Kufeld, R.M., Cross, J.L., Hodge, R.W., Ericson, W.F. and Carter, R.D.G., 1984, "NASA Rotor System Research Aircraft Flight-Test Data Report Helicopter and Compound Configuration”, NASA Technical Memorandum 85843.

[19] Floros, M. and Johnson, W., 2004, "Stability Analysis of the Slowed-Rotor Compound Helicopter Configuration”, American Helicopter Society 60th Annual Forum, Baltimore, Maryland, June 7-10.

[20] Datta, A., Yeo, H. and Norman, T.R., 2011, "Experimental Investigation and Fundamental Understanding of a Slowed UH-60A Rotor at High Advance Ratios", American Helicopter Society 66th Annual Forum, Virginia Beach, Virginia, May 3-5.

[21] Silva, C., Yeo, H. and Johnson, W., 2010, "Design of a Slowed-Rotor Compound Helicopter for Future Joint Service Missions", American Helicopter Society Aeromechanics Specialist's Conference, San Francisco, January 20-22.

[22] Ferguson, K.M. and Thomson, D.G., 2013, "Flight Dynamics Investigation of Compound Helicopter Configurations", American Helicopter Society 69th Annual Forum, Phonix, Arizona, May 22-23.

[23] Johnson, W., Yamauchi, G.K. and Watts, M.E., 2005, "NASA Heavy Lift Rotorcraft System Investigation", NASA/TP-2005-213467.

[24] Russell, C. and Johnson, W., 2012, "Conceptual Design and Performance Analysis for a Large Civil Compound Helicopter”, American Helicopter Society Future Vertical Lift Aircraft Design Conference, San Francisco, California, January 18-20.

[25] Johnson, W., Elmore, J.E., Keen, E., Gallaher, A.T. and Nunez, G.F., 2016, “Coaxial Compound Helicopter for Confined Urban Operations", American Helicopter Society Specialist's Conference on Aeromechanics Design for Vertical Lift, San Francisco, California, January 20-22.

[26] Zhang, T., and Barakos, G.N., 2019, “Towards Optimization of Compound Rotorcraft”, 45th European Rotorcraft Forum, Warsaw, Poland.

[27] Desvigne, D., Coisnon, R., Michel, B.R., Thomas, A., Pinacho, J.P. and Roca Leon E., 2019, "Multi-Objective Optimization Tool for Designing Main-Rotor Blades for High-Speed Helicopter", 45th European Rotorcraft Forum, Warsaw, Poland.

[28] Yin, J., Schwarz, T., Wentrup, M. and Guntzer, F., 2019, "DLR Analysis on the Noise Emission from the RACER Configuration”, 45th European Rotorcraft Forum, Warsaw, Poland. 
[29] Bauknecht, A., Wang, X., Chopra, I., 2019, "Wind Tunnel Test of a Rotorcraft with Lift Compounding", 45th European Rotorcraft Forum, Warsaw, Poland.

[30] Stalewski, W., 2017, "Projektowanie i optymalizacja aerodynamiczna wiropłatów”, (Eng.: "Aerodynamic Design and Optimization of Rotorcraft"), Warsaw, Wydawnictwa Naukowe Instytutu Lotnictwa, ISBN 978-83-63539-40-5 (in Polish).

\title{
SKUTECZNOŚĆ ŚMIGLOWCÓW O ZŁOŻONEJ KONFIGURACJI PRZY ZWIĘKSZANIU OSIĄGÓW WIROPŁATÓW
}

\begin{abstract}
Abstrakt
W pracy przedstawiono wyniki obliczeń umożliwiających porównanie obwiedni stanów lotu dla układu konwencjonalnego śmigłowca $\mathrm{z}$ wirnikiem głównym i śmigłem ogonowym oraz dla śmigłowca złożonego z dodatkowymi skrzydłami generującymi siłę nośną i śmigłami pozwalającymi zwiększyć poziomą siłę napędową. Uproszczony model struktury śmigłowca obejmujący sztywny kadłub i wirnik nośny traktowany jako sztywny dysk, zastosowano do określenia osiągów wiropłata oraz wymaganego zakresu wychyleń układu sterowania. Bardziej złożony model odkształcalnych łopat wirnika z wykorzystaniem metody Galerkina zastosowano do obliczeń obciążeń wirnika i odkształceń łopat w zadanych stanach lotu obejmujących przedział lotów z dużymi prędkościami. Obliczenia przeprowadzono dla danych dotyczących hipotetycznego śmigłowca średniego o masie $6000 \mathrm{~kg}$ i przegubowym połączeniem łopat z głowicą wirnika. Model łopaty odkształcalnej, zgodnie z metodą Galerkina, pozwala wyznaczać odkształcenia łopat jako złożenie składowych pochodzących od uwzględnianych giętnych i skrętnych postaci własnych łopat. Wprowadzenie dodatkowych skrzydeł i pchających śmigieł pozwala zwiększyć zakres prędkości lotu powyżej $300 \mathrm{~km} / \mathrm{h}$. Wyniki obliczeń symulacyjnych przedstawiono w postaci przebiegów czasowych obciążeń wirnika i odkształceń łopat oraz w postaci rozkładów parametrów na dysku wirnika. Metody symulacyjne mogą być zastosowane do zdefiniowania wymagań dotyczących wiropłata dużych prędkości.
\end{abstract}

Słowa kluczowe: śmigłowiec złożony, obciążenia wirnika, odkształcenia łopat. 